Zabytkoznawstwo i Konserwatorstwo XLIV, Toruń 2013

\title{
Technologia i technika uzyskiwania wybranych impastów na podobraziach płóciennych
}

\section{Impast w malarstwie sztalugowym}

T mpast w malarstwie sztalugowym był przejawem zmiany w idei tworzeInia dzieła.

W każdej z najbardziej znanych technik od czasów najdawniejszych do dziś, w technikach wodnych, emulsyjnych, olejnych można znaleźć jego przykłady. Na przestrzeni wieków grubo kładzione warstwy malarskie w postaci impastów odgrywały różną rolę. W tym celu należy rozgraniczyć dwa pojęcia dotyczące użycia impastu - wynikającego z rodzaju zastosowanej farby lub wielowarstwowego nakładania oraz impastu wykonanego przez artystę w sposób świadomy, będący celem samym w sobie lub środkiem składającym się na pełną wartość obrazu. W pierwszym przypadku impast podkreśla w sposób trójwymiarowy poszczególne elementy kompozycji, zazwyczaj w najwyższych światłach. Wynika również z naturalnego śladu po narzędziu i charakteru użytej farby ${ }^{1}$ (Il. 1, il. 2, il. 3).

1 J. Olszewska-Świetlik, Warsztat malarski Mistrza ottarza ze Strzegomia (1486/87), Torun 2002, s. 64; eadem, Warsztat malarski antwerpskiego retabulum sw. Adriana ₹ basyliki Mariackiej w Gdańsku, Toruń 2008, s. 25. 
Należy zaznaczyć, że ten typ impastu najczęściej spotykany jest w malarstwie dawnym, choć nie brakuje go również we współczesnych obrazach. Z kolei impast, którym artysta nieprzypadkowo operuje w celu uzyskania zamierzonej faktury warstwy malarskiej, składa się na „malarstwo impastowe" lub „fakturowe”. Impast jest wtedy zabiegiem celowym, dążącym do wyłonienia ekspresji obrazu, dynamiki materii malarskiej. W malarstwie impastowym nakładano go ,alla prima"3 lub poprzez odpowiednie wielowarstwowe nałożenie farby przy wykorzystaniu różnych narzędzi, głównie pędzli i szpachli. Taki rodzaj impastu eksponował przede wszystkim osobny język wypowiedzi malarskiej każdego artysty, wyrażał niezależność twórczą i indywidualność (Il. 4).

O obrazach zawierających w podobny sposób budowana powierzchnię mówi się również, że są namalowane w „technice impastowej”. Malarstwo impastowe w miarę rozwoju ewoluowało do rozbudowanej, często radykalnej własności reliefu i faktury, szczególnie w obrazach współczesnych. Badacze uzupełniaja impasto „,...] znaczeniem dodatkowym” w porównaniu z klasycznym traktowaniem płaszczyzny obrazu (tj. od renesansu do impresjonizmu $)^{5}$. W twórczości malarskiej do czasów impresjonizmu impast wzmacniał rolę motywu realistycznego i światła, a w malarstwie od końca XIX wieku aktywował ekspresję i „maestrię w operowaniu pędzlem”. Coraz

2 D. Markowski, Ochrona impastowej warstny malarskiej obrazón olejnych na płótnie podczas zabiegón konserwatorskich, Toruń 2002, s. 5.

3 Alla prima (wł. „od razu”) - „technika malowania w sposób bezpośredni, szybko, bez podmalowania [...]. Obrazy olejne mają zróżnicowaną fakturę i wyraźne ślady pociagnięć pędzla [...]", za: Stownik terminologiczny sżtuk pieknych, red. S. Kozakiewicz, wyd. 5, Warszawa 2005 , s. $10-11$.

4 Problem podkreślenia różnicy między impastem, wynikającym z naturalnego śladu narzędzia lub charakteru użytych materiałów malarskich, a impastem odznaczającym się świadomym nałożeniem farby w wysokiej jej strukturze był przedmiotem badań i opracowań technologicznych, na przykład Jonathan Stephenson stwierdził, że odwzorowany dukt pędzla, tworzacy wysoką fakturę, sugeruje formę przedstawienia, a zamierzony gruby impast w kontraście z płaskim podłożem malarskim wzbogaca obraz dodatkowa głębią oraz silniejszym wyobrażeniem tekstury przedmiotów, za: J. Stephenson, The materials and techniques of painting, London 1993, s. 101; P. Majewski, Malarstwo materii w Polsce jako formuta „nowoczesnosici", Lublin 2006, s. 43.

5 P. Majewski, op. cit., s. 43.

${ }^{6}$ Ibidem, s. 43. 
bogatsze i bardziej zróżnicowane nawarstwienia struktur ciężkich mas farby zmuszaja autorów publikacji z zakresu technologii i techniki do uaktualnienia prostej definicji impasto $i$ wzbogacenia jej treści innymi wartościami materii, dotykających sfer faktury. Przykładem jest pojęcie „faktury chropawej”, która jest wynikiem położenia farby impastowo lub pastoso - „w formie gęstej nieprzenikliwej masy"7. W dzisiejszym rozumieniu impast nierozerwalnie łączy się z fakturą obrazu: „Faktura to swego rodzaju rzeźba obrazu”.

\section{Część badawcza}

W części badawczej wyselekcjonowano 49 rodzajów spoiw charakterystycznych dla kilku technik malarskich. Wyboru dokonano na podstawie przepisów, które zostały wymienione w literaturze przedmiotu oraz spośród tych zidentyfikowanych w obiektach zabytkowych. Przeprowadzone doświadczenia miały na celu zwrócenia uwagi na wybrane historyczne i współczesne spoiwa i wypełniacze farb, używane w dawnych i współczesnych warsztatach, analizę ich cech malarskich przydatnych do wykonania impastów oraz określenie ich przydatności do celów artystycznych i konserwatorskich.

\section{II.1. Przygotowanie podłoża}

Podłożami w części doświadczalnej są trzy lniane płótna nabite na krosna ruchome, każde o wymiarach 55x55 cm. Płótna zostały przeklejone 10\% roztworem kleju glutynowego (żelatyna). Następnie nałożono trzy rodzaje barwnych, gładkich z widoczną delikatną faktura płótna zapraw emulsyjnych o różnej chłonności':

I. emulsja typu „olej w wodzie” O/W, wodorozcieńczalna - „chuda”,

II. emulsja typu „olej w wodzie” O/W, wodorozcieńczalna - „półtłusta”, III. emulsja typu „woda w oleju” W/O - nierozcieńczalna w wodzie „tłusta”.

A. Osęka, Spojrzenie na sæzuke, Warszawa 1987, s. 84.

Ibidem, s. 85.

9 M. Doerner, Materialy malarskie i ich zastosowanie, Warszawa 1975, s. 30-33. 


\section{Zaprawy:}

I. Emulsja typu O/W- zaprawa „chuda”

Spoiwo:

1 cz. obj. 7\% roztworu kleju glutynowego (żelatyna spożywcza)

$1 / 3$ cz. obj. pokostu lnianego (gotowy pokost lniany firmy Renesans)

1 cz. obj. wody

1 cz. obj. kredy $\mathrm{CaCO}_{3}$ (firmy Kremer)

1 cz. obj. czerwieni żelazowej (48120 firmy Kremer)

II. Emulsja typu O/W - zaprawa „półtłusta”

Spoiwo:

1 cz. obj. 7\% roztworu kleju glutynowego (żelatyna spożywcza)

$1 / 2$ cz. obj. pokostu lnianego (gotowy pokost lniany firmy Renesans)

$1 / 2$ cz. obj. wody

1 cz. obj. kredy (firmy Kremer)

1 cz. obj. czerwieni żelazowej (nr 48120 firmy Kremer)

III. Emulsja typu W/O - zaprawa „tłusta”

A. spoiwo:

1 cz. obj. 7\% roztworu kleju glutynowego (żelatyna spożywcza)

1 cz. obj. pokostu lnianego (gotowy pokost lniany firmy Renesans)

1 cz. obj. czerwieni żelazowej (nr 48120 firmy Kremer)

niewielki dodatek kredy $\mathrm{CaCO}_{3}$ (firmy Kremer)

B. cienka powłoka nałożona na jedną warstwę zaprawy ,tłustej” (spoiwo A)

olejna farba („czerwień żelazowa” nr 3 firmy Renesans)

pokost lniany ${ }^{10}$ do połączenia $z$ odchudzona gotowa farbą olejna

Wszystkie trzy zaprawy na początkowym etapie przygotowano w następujący sposób: rozpuszczono klej glutynowy na ciepło w wodzie. Ostudzony roztwór kleju połączono pędzlem z czerwienią żelazową i kredą. Ogrzano mieszaninę w kappieli wodnej. Po ostudzeniu wkraplano za pomoca kroplomierza gotowy pokost lniany firmy Renesans, energicznie mieszając. W przypadku zapraw I „chudej” i II „półtłustej” po

10 Pokost lniany przygotował Pan Bogusław Andruchowicz w Zakładzie Technologii i Technik Malarskich UMK. Olej lniany gotowano z dodatkiem octanu kobaltu $\mathrm{Co}\left(\mathrm{CH}_{3}\right.$ COO) $4 \mathrm{H}_{2} \mathrm{O}$ w ilości $0,49 \mathrm{~g}$ na $100 \mathrm{~cm}^{3}$ oleju w łaźni piaskowej w temperaturze $200^{\circ} \mathrm{C}$. 
dodaniu odpowiedniej ilości pokostu, wlano wodę i wymieszano. „Chudą" i „półtłustą” zaprawę nałożono dwukrotnie, posługując się szpachlą oraz pędzlem.

W przypadku zaprawy III „tłustej” wystapiły trudności podczas końcowego etapu wkraplania pokostu - składniki wodne oddzieliły się od oleistych $\mathrm{w}$ trakcie nakładania zaprawy na płótno. $\mathrm{Na}$ odwrociu podobrazia zaobserwowano tłustą powłokę spowodowaną wchłonięciem przez płótno oleju z zaprawy, na licu zaś chropowata warstwę pozbawioną spoiwa.

Zdecydowano się przygotować kolejną „tłustą” zaprawę w ten sam sposób, ale z niewielkim dodatkiem kredy. Zaprawa nakładała się bardzo dobrze, jednak w kilku miejscach zaobserwowano poczatkowe stadium oddzielania się składników zaprawy.

Ze względu na niezadowalający efekt związany z różną chłonnością partii powierzchni zaprawy tłustej zdecydowano się na nałożenie izolacji w postaci cienkiej warstwy farby olejnej firmy Renesans (czerwień żelazowa), z której uprzednio odsączono nadmiar spoiwa olejnego za pomoca chłonnego papieru i połączono z niewielkim dodatkiem pokostu lnianego. Uzyskano dobrą półgładką powierzchnię.

\section{II.2. Sposób przygotowania spoiw i wybór wypełniaczy}

Do każdego wybranego spoiwa w części doświadczalnej jako wypełniacz zastosowano biel tytanowa ze względu na powszechność tego pigmentu w dzisiejszej praktyce malarskiej. W większości receptur i podań wybranych tutaj przykładów używano bieli ołowiowej. Ze względu na trujący charakter, biel ołowiowa została dzisiaj w dużej mierze wyparta innymi, mniej toksycznymi pigmentami. Dlatego zdecydowano się na wykorzystanie bieli tytanowej jako wypełniacz we wszystkich przeprowadzonych próbach impastów.

Suchy pigment przed zmieszaniem ze spoiwami wodnymi i emulsyjnymi łączono z wodą aż do uzyskania gęstej „pasty”, którą ucierano za pomoca szpachli na płycie szklanej. Spoiwa olejne ucierano bezpośrednio z suchym pigmentem. Następnie pigment łączono ze spoiwem szpachlą na płycie szklanej lub ucierano w moździerzu w przypadku, kiedy nastapiły trudności w połączeniu spoiwa i wypełniacza. 
Spoiwa klejowe i emulsyjne uzyskiwano poprzez ucieranie w moździerzu lub poprzez wstrząsanie w zamykanym naczyniu. Inne niekiedy wymagały podgrzania (spoiwa woskowe, kazeinowe). Spoiwa olejno-żywiczne uzyskiwano przez łączenie składników w łaźni wodnej i mieszanie pędzlem lub w moździerzu. Gotową farbę ze spoiwem w wybranych przypadkach dodatkowo mieszano z wypełniaczami (piaskiem i kreda) pędzlem na płycie szklanej.

Impasty wykonywano w 5 różnych określonych próbach:

- próba 1 - farba gęsta $z$ większym dodatkiem pigmentu lub w zależności od rodzaju techniki, mniejszą ilością spoiwa (20-30 kropel spoiwa na $5 \mathrm{~cm}^{3}$ suchego pigmentu) lub medium. W zależności od rodzaju farby w próbie 1 znajduja się te impasty, których przepisy nie opierają się na stosunku spoiwa i pigmentu, ale stosunku wcześniej wykonanych różnych rodzajów farb. Informowane jest to na bieżąco w wynikach impastów,

- próba 2 - farba o konsystencji „rzadszej” z większą ilością spoiwa (30-50 kropel spoiwa na $5 \mathrm{~cm}^{3}$ suchego pigmentu),

- próba 3 - farba (30-35 kropel spoiwa na $\left.5 \mathrm{~cm}^{3}\right)$ nakładana szpachla,

- próba 4 - farba (30-35 kropel spoiwa na $\left.5 \mathrm{~cm}^{3}\right)$ z dodatkiem wypełniacza strukturalnego - drobnoziarnistego piasku,

- próba 5 - farba (30-35 kropel spoiwa na $\left.5 \mathrm{~cm}^{3}\right)$ z dodatkiem wypełniacza zagęszczającego w postaci kredy.

\section{Wyniki}

Podziału analizowanych spoiw dokonano ze względu na charakter związany z możliwością rozcieńczaniem woda - spoiwa tzw. chude i te nierozcieńczane w wodzie - tzw. tłuste. Badano zestaw spoiw w różnych kombinacjach. Recepty sa złożone i zawieraja różnego rodzaju dodatki w postaci mediów, których zadaniem jest ulepszenie właściwości farby, takich jak na przykład: elastyczność, higroskopijność, przyczepność do podłoża, odporność na zmiany barwne, czas wysychania, konsystencja.

Istotne było przeanalizowanie możliwości uzyskiwania impastów na podobraziach płóciennych z wykorzystaniem trzech typów zapraw: tzw. 
chudej i półtłustej - typ emulsji olej w wodzie (o/w) z różnym procentem ilości składnika olejnego oraz tzw. tłustej - typu woda w oleju.

Analizowano wpływ rodzaju zaprawy na możliwość uzyskania impastów, biorąc pod uwagę adhezję impastu do podłoża. Zaprawy tzw. chude charakteryzuje skłonność do absorbowania spoiwa z warstw malarskich. Powyższą cechę można zniwelować, stosując izolację lub dodając większą procentową ilość składnika olejnego do spoiwa zaprawy. „Chuda” zaprawa emulsyjna okazała się dobrym podłożem malarskim głównie dla spoiw wodorozcieńczalnych. Zaprawy emulsyjne typu „olej w wodzie” ze zwiększonym składnikiem oleju, czyli tzw. „półtłuste”, charakteryzują się lepszą elastycznością i mniejszym stopniem „chłonięcia” spoiw z warstwy malarskiej. Jest na tyle elastyczna, aby niekiedy zrekompensować brak tej cechy w spoiwach o niskiej elastyczności, co stwierdzono w kilku przypadkach „chudych" spoiw wodorozcieńczalnych. Natomiast nie jest tak bardzo chłonna jak „chuda”, przez co nie wchłania nadmiaru spoiwa farb, co miało miejsce w przypadku bardzo tłustych spoiw olejno-żywicznych i olejnych. „Tłusta” jest najbardziej elastyczną wśród trzech badanych zapraw. Niestety, zbyt tłuste spoiwo może wpływać na zmiany optyczne nakładanych farb. Śliska powierzchnia najczęściej utrudnia kontrolę podczas malowania.

Stwierdzono, że na jakość i estetykę impastów wpływają: gęstość farby, czas schnięcia, odporność na zmiany optyczne i możliwości fakturalne. Pod względem konsystencji najlepiej sprawdzają się gęste farby, umożliwiające pozostawienie trwałych w pierwotnie pozostawionej masie impastów (spoiwa nierozcieńczalne w wodzie: olejno-żywiczne, olejne, woskowe, olejno-epoksydowe). Zbyt gęsta konsystencja z kolei utrudnia twórczy, nierzadko szybki proces aplikacji (niektóre spoiwa białkowe na bazie żółtka, woskowe). Tutaj najlepiej sprawdza się szpachla, która pod naciskiem w szybszy sposób zakryje podłoże. Z drugiej strony farby rzadkie umożliwiają otrzymanie ciekawych plastycznych w formie impastów, które można dowolnie kształtować w trakcie pracy (spoiwa wodorozcieńczalne: klejowe, gumowe, kazeinowe, akrylowe). Stwierdzono, że w pracy twórczej, jak i konserwatorskiej niezbędne jest poznanie czasu schnięcia farby. Kilkudniowy lub kilkugodzinny proces wysychania pozwala na zastanowienie się nad formą i możliwość zmian koncepcji estetycznej. Zbyt długie schnięcie impastów wymaga pewnej dyscypliny pracy. Najlepszym czasem przy- 
datnym w opracowywaniu impastów charakteryzują się są spoiwa wodorozcieńczalne kazeinowe, akrylowe i woskowe. Żadne ze składników spoiw nie sa całkowicie odporne na naturalne procesy starzenia oraz zmiany pod wpływem warunków atmosferycznych. Spoiwo olejne żółknie, dlatego najlepiej korzystać z oleju polimeryzowanego lub gotowanego. Starzenie spoiw żywic sztucznych podyktowane jest typem żywicy, a takie materiały jak gliceryna, miód czy jajo kurze w podwyższonych warunkach atmosferycznych mogą okazać się nieodporne na mikroorganizmy. Najbardziej trwałymi pod względem stabilności optycznej są spoiwa wodorozcieńczalne: klejowe, gumowe i akrylowe z ograniczoną ilością składnika w postaci oleju. Potwierdzono wpływ wypełniaczy w postaci kredy i piasku na jakość faktury impastu. Piasek, oprócz głównej roli nadania warstwie malarskiej cech określonej faktury, polepszał niekiedy adhezję, jak i chronił impast przed spękaniem (np. spoiwa wodorozcieńczalne: Impast 4, 6 - węglowodanowe na bazie gum roślinnych, 7, 8 - białkowe na bazie żółtka i białka jaja oraz 17, 21 - kazeinowe). W przypadku niektórych spoiw wodorozcieńczalnych kredą można było wyeliminować tendencję do spękań (np. Impasty 17 i 19 - kazeinowe lub jajowe - 5), niekiedy korzystnie wpływała na czas wysychania oraz wspomagała schnięcie impastu w całej masie (spoiwa nierozcieńczalne w wodzie olejno-żywiczne i olejne).

Po wykonaniu prób analizowano:

- przyczepność do podłoża,

- możliwość uzyskiwania wysokich warstw bez tendencji do odspajania i kruszenia impastów,

- uzyskiwanie plastycznych efektów:

- fakturę,

- wygląd powierzchni - błyszczenie i matowość.

Rodzaje impastów podzielono wg możliwości tych rozcieńczanych wodą oraz nierozcieńczalnych.

I. Spoiwa białkowe

1. na bazie kleju glutynowego:

- wodorozcieńczalne:

- Impast nr 1 (50 g 5 \% roztworu kleju skórnego, 2 g gumy tragankowej (w postaci suchej), kilka kropel gliceryny, $15 \mathrm{~cm}^{3}$ bieli tytanowej) 
- Impast nr 1A (spoiwo to jest drugim wariantem spoiwa wykorzystanego w „Impaście nr 1”11, 48 cz. obj. 5\% roztworu kleju skórnego, 48 cz. obj. 4 \% gumy tragankowej (roztwór gumy tragankowej), 4 cz. obj. gliceryny, 15 $\mathrm{cm}^{3}$ bieli tytanowej)

- Impast nr 212 (1 cz. obj. farby temperowej $(1 \mathrm{cz}$. obj. żółtka, 1 cz. obj. octu winnego, $15 \mathrm{~cm} 3$ bieli tytanowej), 0,25 cz. obj. 5\% kleju kostnego)

- Impast nr 2A (zdecydowano się na przygotowanie farby nr 2 w inny sposób ze względu na brak podanych informacji na temat farby temperowej. Zmieniono również rodzaj kleju.

1 cz. obj. farby temperowej (1 cz. obj. żółtka jaja,

1 cz. obj. oleju gotowanego13, $15 \mathrm{~cm} 3$ bieli tytanowej), 0,25 cz. obj. 5\% kleju skórnego) (Il. 5-6A)

Spoiwa te nie nadają się do nanoszenia wysokich impastów na podobraziu płóciennym ze względu na niską elastyczność, powodującą spękania. W niższych warstwach zachowują się lepiej, głównie na zaprawie „chudej”. Można poprawić ich elastyczność poprzez dodanie piasku (Impasty $n r 1,2,2 A)$. Dodatek strukturalny najlepiej wpłynął na Impast $n r$, gdyż tylko w tej próbie - próbie nr 4 - warstwa malarska wykazywała się najlepsza adhezja, dodatkowo na zaprawie „tłustej”. Kreda „odchudziła” farbę o spoiwach „chudych” białkowych, co w konsekwencji spowodowało szybkie kruszenie naniesionych impastów. Mimo złych wyników, farby na przykładzie Impastów 1, 2 i 2A, nadających się do niskich warstw, można wykorzystać ze względu na gęstą konsystencję, nawet z większą ilością spoiwa

11 Mowa o gumie tragankowej w roztworze kleju, dlatego zdecydowano się wykonać dwa spoiwa z gumą tragankowa rozpuszczoną w roztworze kleju oraz roztworem gumy tragankowej w roztworze kleju kostnego, za: S. Hackney, R. Jones, J. Townsend, Paint and Purpose. A study of technique in British Art, London 1999, s. 68.

12 Technika wykorzystująca to spoiwo nazywana jest De trempe á la colle (klej i tempera). Proporcje składników zostały dobrane przez autora niniejszej pracy. Edgar Degas wykorzystał tę technikę w obrazie Tancerki na linie z.1876 roku. Farby nakłada się na ciepło, za: M. Doerner, op. cit., s. 238.

13 Olej lniany gotowany został przygotowany w Zakładzie Technologii i Technik Malarskich UMK w Toruniu. 
próby 2, do powłok zachowujących delikatny dukt pędzla. Wszystkie badane spoiwa są odporne na zmiany barwy oraz wykazują krótki czas wysychania. Impasty charakteryzuje matowa lub półmatowa powłoka.

2. Na bazie jaja kurzego:

- wodorozcieńczalne:

- $\quad$ zólttko jaja - Impast nr 7 (1 cz. obj. zółttka jajka kurzego, 1 cz. obj. octu winnego, $15 \mathrm{~cm}^{3}$ bieli tytanowej)

- białko jaja - Impast nr $8^{14}(1 / 4$ cz. obj. roztworu ałunu (1:10 w wodzie), $1 \mathrm{cz}$. obj. białka ${ }^{15}, 15 \mathrm{~cm}^{3}$ bieli tytanowej - Impast nr 9 (spoiwo to jest wariantem spoiwa Impastu $n r 8$ 1/4 cz. obj. roztworu ałunu (1:10 w wodzie), 1 cz. obj. białka, $1 /{ }_{3}$ cz. obj. $10 \%$ żywicy mastyksowej w olejku terpentynowym, $15 \mathrm{~cm}^{3}$ bieli tytanowej) (Il. 7-8A)

- $\quad$ całe jajo - Impast nr $14^{16}$ (1 cz. obj. całego jajka, $1 \mathrm{cz}$. obj. $25 \%$ mastyksu w olejku terpentynowym, 1 cz. obj. wody, kilka kropel zagęszczonego oleju, $15 \mathrm{~cm}^{3}$ bieli tytanowej)

- emulsja żółtkowa - typu „olej w wodzie” - Impast $\underline{\mathrm{nr} 10^{17}}$ (1 cz. obj. bieli temperowej (1 cz. obj. żółtka, 1 cz. obj. octu winnego, $5 \mathrm{~cm}^{3}$ bieli tytanowej), 1 cz. obj. farby olejnej $\left(5 \mathrm{~cm}^{3}\right.$ suchego pigmentu, olej lniany sykatywowany $\left.{ }^{18}\right)$

- Impast nr $11^{19}$ (1 cz. obj. żółtka jajka kurzego, 1 cz. obj. farby olejnej (olej lniany firmy Renesans, $15 \mathrm{~cm}^{3}$ bieli tytanowej)_

14 M. Doerner przypisuje temu spoiwu przydatność do impastów, za: M. Doerner, op. cit., s. 142.

15 Świeże białko ubito na pianę. Odstawiono aż do upłynnienia.

16 Spoiwo to wykorzystywał Otto Dix. Farbę o tym spoiwie malarz nakładał w kilku warstwach aż do uzyskania ,silnego impastu”, za: M. Doerner, op. cit., s. 246.

17 A. P. Laurie, The painter's Methods and Materials, London 1983, s. 165.

18 Olej lniany sykatywowany - pokost lniany został przygotowany w Zakładzie Technologii i Technik Malarskich UMK w Toruniu.

19 Spoiwo to charakterystyczne jest dla Otto Dixa, niemieckiego malarza początku XX wieku, za: M. Doerner, op. cit., s. 247. 
Spoiwa białkowe na bazie jaja kurzego najlepiej zachowuja się na zaprawie „chudej” i „półtłustej”. Na zaprawie „tłustej” dobre wyniki wykazuja impasty z dodatkiem piasku (Impast 7 i 8), który ma wpływ na lepszą przyczepność. Cechą charakterystyczną dla tych spoiw jest dobra stabilność optyczna, jak i niezbyt gęsta konsystencja (oprócz spoiwa jajowo-żywicznego), przekreślająca uzyskiwanie wysokich impastów. Ograniczenie ilości spoiwa, powoduje zagęszczenie farby (próba 1), przede wszystkim w Impastach 7, 9, co w następstwie prowadzi do kruszenia bieli. Zbyt gęsta konsystencja z kolei uniemożliwia swobodne posługiwanie się pędzlem szczecinowym. Lepsze wyniki wykazuje szpachla, która pod wpływem siły nacisku dobrze rozprowadza farby w cienkich warstwach. Dodatek żywiczny w spoiwie Impastu 14 powodował szybkie gęstnienie bieli, co hamowało swobodne malowanie. Impasty o tym spoiwie szybko pękają w grubych warstwach. Podobnie było w przypadku spoiw na bazie białka kurzego (Impasty $n r 8$ i 9). Dodatek żywicy mastyksowej Impastu nr 9, w porównaniu z tożsamym spoiwem Impastu $n r$, spowodował zagęszczenie oraz szybkie pojawienie się krakelur w warstwie malarskiej. Dodatek piasku niekiedy polepszał przyczepność do podłoży.

- nierozcieńczalne w wodzie:

- emulsja żółtkowa - typu ,woda w oleju” - Impast nr $12^{20}$ (1 cz. obj. farby olejnej (olej lniany firmy Renesans, $5 \mathrm{~cm}^{3}$ bieli tytanowej), $1 / 2 \mathrm{cz}$. obj. farby temperowej $(1 \mathrm{cz}$. obj. żółtka, $1 \mathrm{cz}$. obj. octu winnego, $5 \mathrm{~cm}^{3}$ bieli tytanowej), kilka kropel wody, ${ }^{1} / 2$ cz. obj. żółtka jajka kurzego)

- Impast nr $13^{21}(1 \mathrm{cz}$. obj. bieli temperowej $(1 \mathrm{cz}$. obj. żółtka, 1 cz. obj. octu winnego, $5 \mathrm{~cm}^{3}$ bieli tytanowej), 3 cz. obj. farby olejnej (olej lniany sykatywowany, $5 \mathrm{~cm}^{3}$ bieli tytanowej)

- Impast nr $15^{22}$ (1 część jajka (całe jajko), 1 część mastyksu (25\% mastyks w olejku terpentynowym),

20 M. Doerner, op. cit., s. 216.

${ }^{21}$ Spoiwo to charakterystyczne jest dla El Greca - XVII-wiecznego hiszpańskiego malarza wykorzystującego impast w malarstwie, za: ibidem, s. 218.

22 Ibidem, s. 247. 
$10 \mathrm{~cm}^{3}$ bieli tytanowej, 1 część farby olejnej (olej Iniany firmy Renesans, $5 \mathrm{~cm}^{3}$ bieli tytanowej)) (Il. 19-20A)

- Impast nr $16^{23}$ (3 cz. obj. zółtka jaja kurzego, 1-2 cz. obj. damary (roztwór żywicy damarowej w terpentynie 1:1), $1 \mathrm{cz}$. obj. terpentyny, $15 \mathrm{~cm}^{3}$ bieli tytanowej)

Spoiwa te wykazywały lepsze wyniki w uzyskiwaniu wysokich warstw na wszystkich rodzajach zaprawy. Powłoki impastów są półmatowe lub bardziej połyskujące. Warstwa malarska nawet z dużą ilościa pigmentu nie kruszy się, wykazuje się dobra adhezją do trzech rodzajów zapraw. Inaczej zachowywał się Impast nr 16, którego warstwy malarskie szybko popękały i odspajały się, Impast nr 15, który wymagał mniejszego dodatku spoiwa, aby jego konsystencja nadawała się do plastycznych struktur. Zbyt duży dodatek pigmentu sprawiał, że niemożliwe było swobodne nakładanie pędzlem na podobrazia. Wypełniacz strukturalny w większości przypadków (oprócz Impastu 10) stabilizował impasty.

3. Na bazie kleju kazeinowego:

- wodorozcieńczalne:

- $\quad$ na bazie kleju kazeinowego - Impast nr $18^{24}(1 \mathrm{cz}$. obj. roztworu kazeiny ${ }^{25}, 1 \mathrm{cz}$. obj. olejku terpentynowego, $1 \mathrm{cz}$. obj. terpentyny weneckiej, $15 \mathrm{~cm}^{3}$ bieli tytanowej) (Il. 9-10A)

- Impast $19^{26}$ (2 cz. obj. kleju kazeinowego (roztwór kazeiny $^{27}$ ), 1 cz. obj. werniksu damarowego (wer-

23 P. Frączek, Rekonstrukcja techniki temperowej w malarstwie XV w. na praykeładzie wybranych obrazón z. Muгeum w Toruniu, praca magisterka pod kier. prof. J. Flika, Toruń 1996, s. 23.

24 P. Frączek, Rekonstrukcja..., s. 24.

$251000 \mathrm{~g}$ sera chudego, świeżego; $150 \mathrm{~g}$ boraksu w 0,5 1 wody. Do sera przetartego przez sito wsypuje się boraks, zalewa $500 \mathrm{~g}$ wody. Po kilku godzinach tworzy się jednolita masa. Pozostałe składniki emulsji dodawano miesza się na zimno w moździerzu. Spoiwo kazeinowe wykonano wg przepisu, za: J. Flik, Portret Mikotaja Kopernika z. Mužeum Okregowego w Toruniu. Studium warsztatu malarskiego, Torun 1990, s. 37.

26 P. Frączek, Rekonstrukcja..., s. 24.

27 Patrz przypis 24. 
niks firmy Renesans), 0,2 cz. obj. $10 \%$ tymolu, 15 $\mathrm{cm}^{3}$ bieli tytanowej)

- Impast $21^{28}$ (10 cz. obj. lakieru mastyksowego (1 cz. mastyksu i 3 cz. olejku terpentynowego), 8 cz. obj. drobno pokruszonego wosku (rozpuszczonego w malej ilości terpentyny), 10 cz. obj. roztworu kazeiny, $10 \mathrm{cz}$. obj. wody, $15 \mathrm{~cm}^{3}$ bieli tytanowej) - emulsja kazeinowa - typu „olej w wodzie” - Impast nr 17 (1 cz. obj. roztworu kazeiny ${ }^{29}, 1$ cz. obj. oleju lnianego (olej lniany gotowany), $15 \mathrm{~cm}^{3}$ bieli tytanowej)

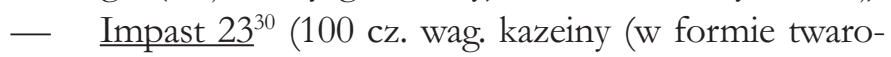
gu), $250 \mathrm{cz}$. wag. wody, 8 cz. wag. amoniaku (użyto boraksu), $50 \mathrm{cz}$. wag. oleju makowego, $15 \mathrm{~cm}^{3}$ bieli tytanowej)

Spoiwa nadają się do niskich impastów. Badania pokazały, że im więcej spoiwa, tym grube warstwy zachowuja się lepiej na trzech typach zapraw (z wyjatkiem Impastu $n r$ 18, 20, w ich warstwie malarskiej pojawiły się mikrospękania), z drugiej strony ta sama ilość spoiwa powoduje rzadką konsystencję niwelująca uzyskanie zamierzonej formy wysokiego impastu - w trakcie wysychania impasty ,zapadają się”. W większości przypadkach dodatki obu wypełniaczy - kredy i piasku - obniżały adhezję do podłoża, spoistość farby zaś jest dobra. W przypadku Impastón $n r$ 19, 20, 23, najgorsza przyczepnością charakteryzował się Impast nr 19, o spoiwie z dodatkiem werniksu damarowego. „Chudy” charakter spoiw, o niskiej elastyczności, wymaga malowania na „chudym” podłożu. Dodatek wosku do spoiwa Impastu nr 21 poprawił elastyczność. Dzięki niemu farba charakteryzuje się trwałością, nawet na zaprawie „tłustej”. Najlepiej zoptymalizować ilość dodawanego spoiwa i przeprowadzić przed użyciem próby: zbyt mała ilość spoiwa w porównaniu do ilości pigmentu w farbie powoduje szyb-

\footnotetext{
28 Spoiwo takie nadaje się do techniki pastoso, za: L. Losos, Techniki malarskie, Warszawa 1991 , s. 70.

29 Do spoiwa wykorzystano tę samą, co w Impastach nr 18, 19, 20, 21, 22, 23, wcześniej przygotowaną kazeinę (patrz przypis 24).

30 Farba o takim spoiwie jest przydatna do uzyskania warstw pastoso, za: L. Losos, op. cit., s. 70 .
} 
kie pękanie, nawet na „chudej” zaprawie, zbyt duża z kolei utrudnia nakładanie kontrolowanych form impastów. Przydatną cechą spoiw kazeinowych jest stabilność optyczna, pod warunkiem ograniczenia składnika oleistego.

- nierozcieńczane w wodzie:

- emulsja kazeinowa - typu „woda w oleju” - Impast nr $22^{31}$ (1 cz. obj. tempery kazeinowej $(3$ cz. obj. roztworu kazeiny, 1 cz. obj. oleju lnianego gotowanego, 5 $\mathrm{cm}^{3}$ bieli tytanowej), $1 \mathrm{cz}$. bieli olejnej (olej lniany sykatywowany, $5 \mathrm{~cm}^{3}$ bieli tytanowej) (Il. 21-22A)

To spoiwo nadaje się do otrzymywania impastów (Impasty $n r$ 17, 22) - po dodaniu kredy, dodatkowo wzbogaconych łagodnym duktem pędzla (22). Farbami o tym spoiwie można osiagnąć różne efekty malarskie, posługując się pędzlem i szpachlą. Odznaczają się dobrą adhezją do wszystkich typów zapraw. Czas schnięcia jest przydatny w formowaniu zamierzonych struktur i opracowywaniu w mokrej farbie już na podłożu. Dodatek kredy i piasku sprzyja uzyskiwaniu ciekawych faktur, bez wyraźnych spękań. Odporność na zmiany optyczne tego rodzaju spoiw uzależniona jest od ilości i jakości oleju.

\section{Spoiwa węglowodanowe (na bazie gum roślinnych)}

- wodorozcieńczalne:

- na bazie gum roślinnych - Impast nr $4^{32}(1 \mathrm{cz}$. obj. roztworu gumy arabskiej (1:2), 1 cz. obj. roztworu gumy śliwowej (1:2), kilka kropel miodu, $1 / 2$ cz. obj. octu winnego, kilka kropel żółtka jajka kurzego, $1 / 3$ cz. obj. 4\% roztworu gumy tragankowej, $15 \mathrm{~cm}^{3}$ bieli tytanowej)

- emulsje gumowe - typu ,olej w wodzie” - Impast nr $3^{33}$ (5 cz. obj. gumy arabskiej, 10 cz. obj. wody, 1-3 cz. obj. gliceryny, 10-20 cz. obj. oleju polimeryzowanego (olej lniany gotowany), $15 \mathrm{~cm}^{3}$ bieli tytanowej)

31 Spoiwo to nadaje się do uzyskania impastów, za: M. Doerner, op. cit., s. 109.

32 Proporcje spoiwa zostały dobrane przez autorkę.

33 B. Slanský, Technika malarstwa, t. 1, Warszawa 1965, s. 247. 
- $\quad$ Impast nr $5^{34}$ (5 cz. obj. roztworu gumy arabskiej (1:2), 1 cz. obj. oleju lnianego (firmy Renesans), 1 cz. obj. werniksu damarowego (roztwór żywicy damarowej w terpentynie 1:2), $4 \mathrm{cz}$. obj. gliceryny, $15 \mathrm{~cm}^{3}$ bieli tytanowej) (Il. 11-12A)

- $\quad$ Impast nr $6^{35}$ (5 cz. obj. roztworu gumy śliwowej (4\%), 2 cz. obj. oleju lnianego (firmy Renesans), 2 cz. obj. werniksu damarowego (roztwór żywicy damarowej w terpentynie 1:2), 4 cz. obj. gliceryny, $15 \mathrm{~cm}^{3}$ bieli tytanowej)

Spoiwa te nie nadaja się do wysokich impastów. Warstwa malarska o spoiwie gumowym wodorozcieńczalnym wykazuje niską elastyczność do podobrazi płóciennych. Badania wykazały, że najlepsze wyniki uzyskały farby o tym spoiwie na zaprawie „tłustej”. Prawdopodobnie z powodu elastycznych składników spoiwa: Impast nr 4 z dodatkiem miodu, żółtka i Impast nr 5 i $6 \mathrm{z}$ olejem, dzięki którym możliwe jest osiaganie średniej wysokości warstwy, nawet na zaprawie „tłustej”. Na zaprawie „chude”” farby wykazywały gorszą adhezję. Lepszej adhezji sprzyja również dodatek gliceryny, który nieznacznie poprawił przyczepność, jak i spoistość. Stwierdzono, że można polepszyć właściwości adhezyjne dodatkiem piasku (Impast nr 4). Dodatek wypełniaczy, w szczególności kredy, nie sprzyja dobremu zachowaniu się warstwy malarskiej ze stosunkowo dużą ilością pigmentu. Im farba jest gęściejsza, w próbie 1, tym ilość kredy powinna być bardziej ograniczona $(5,0)$. Przykład Impastu nr 6 pokazał, że kreda może stabilizować warstwę impastu, podczas gdy nie zaobserwowano pozytywnych wyników w pozostałych próbach. Impast nr 3 lepiej zachowuje się na chudszych zaprawach, z kolei na zaprawie „tłustej” - farba wyraźnie się perliła. Impasty maja powłokę matową oraz charakteryzują się dość dobrą stabilnościa optyczna, oprócz Impastu nr 6, prawdopodobnie ze względu na składnik oleju lnianego gorszej kategorii.

\section{Spoiwa olejno-żywiczne}

- nierozcieńczalne w wodzie:

34 Ibidem, s. 247.

35 W. Ślesiński, Techniki malarskie - spoiwa organiczne, Warszawa 1984, s. 265. 
- Impast nr $24^{36}$ (1 cz. obj. oleju lnianego (firmy Renesans), $1 / 3$ cz. obj. terpentyny weneckiej, $15 \mathrm{~cm}^{3}$ bieli tytanowej)

- Impast nr $25^{37}$ (1 cz. obj. oleju lnianego (firmy Renesans), olejek terpentynowy do rozcieńczania, $1 / 5$ cz. obj. terpentyny weneckiej, $15 \mathrm{~cm}^{3}$ bieli tytanowej)

- Impast nr $26^{38}$ (1 cz. obj. oleju lnianego sykatywowanego, 1 cz. obj. mastyks w olejku terpentynowym 1:2, $15 \mathrm{~cm}^{3}$ bieli tytanowej) (Il. 23-24A)

- Impast nr 27 (spoiwo to jest wariantem spoiwa Impastu nr 26, 1 cz. obj. oleju lnianego sykatywowanego, 1 cz. obj. mastyksu w olejku terpentynowym 1:2, kilka kropel wosku pszczelego (rozpuszczonego na ciepło na łaźni wodnej), $15 \mathrm{~cm}^{3}$ bieli tytanowej)

- Impast nr 28 ${ }^{39}$ (1 cz. obj. oleju orzechowego (firmy Maimeri), 1 cz. obj. mastyksu w olejku terpentynowym 1:2, $15 \mathrm{~cm}^{3}$ bieli tytanowej)

- Impast nr $29^{40}$ (1 cz. obj. oleju orzechowego (firmy Maimeri), $1 /{ }_{3}$ cz. obj. terpentyny weneckiej, $1 / 3$ cz. obj. mastyksu w olejku terpentynowym 1:2, $15 \mathrm{~cm}^{3}$ bieli tytanowej)

- Impast nr $30^{41}\left(1 / 3\right.$ cz. obj. werniksu mastyksowego $\mathrm{O}^{42}, 2 / 3 \mathrm{cz}$. obj. oleju makowego (firmy Maimeri), $15 \mathrm{~cm}^{3}$ bieli tytanowej)

- Impast $\mathrm{nr} 31^{43}$ (1 cz. obj. oleju makowego (firmy Maimeri), 1 cz. obj. damary rozpuszczonej w terpentynie w stosunku 1:2,

36 Spoiwo to nazwane jest przez autora „ciałem gęstopłynnym”, za: B. Slanský, op. cit., s. 325.

37 J. Hopliński, Farby i spoiwa malarskie, Wrocław-Kraków-Gdańsk-Lódź 1990, s. 111.

38 Spoiwo to w literaturze obcojęzycznej to megilp. Wykorzystywał je m.in. William Turner - angielski malarz XIX wieku operujący wysokim swobodnym impastem, za: S. Hackney, Paint and Purpose..., s. 50.

39 Stosowal je Van Dyck, za: M. Doerner, op. cit., s. 224.

40 Spoiwa tego mógł używać Rembrandt, za: ibidem, s. 230.

41 Spoiwa tego używał malarz Stieler, za: ibidem, s. 207.

42 Werniks przygotował mgr Tomasz Szymczak w Zakładzie Technologii i Technik Malarskich UMK w Toruniu. Rozpuszczono 5 gramów żywicy mastyksowej w 45 mililitrach pokostu na łaźni wodnej, uzyskując 10\% werniks mastyksowy.

43 Slanský zawarł przepis spoiwa jako „tradycyjne medium”, za: B. Slanský, Technika..., s. 178. 
biel olejna tytanowa (olej lniany sykatywowany, $15 \mathrm{~cm}^{3}$ bieli tytanowej))

- Impast nr $32^{44}$ (1 część oleju lnianego (firmy Blik), 1 część damary rozpuszczonej w terpentynie w stosunku 1:2, biel olejna tytanowa (olej lniany sykatywowany, $15 \mathrm{~cm}^{3}$ bieli tytanowej))

Spoiwa nadają się do uzyskiwania impastów na wszystkich rodzajach zaprawy. Należy zwrócić uwagę na zbyt „chude” zaprawy, które łatwo i szybko wchłaniają tłuste składniki spoiwa, pozostawiając ciemne otoki wokół pozostawianych impastów. Z drugiej strony, jeśli nie przeszkadza to odbiorze estetycznemu, warstwy stają się bardziej matowe. Im więcej składnika żywicznego, tym farba jest bardziej połyskliwa (zmatowić powierzchnię może dodatek kredy, który stabilizuje wysokie warstwy i powoduje zagęszczenie wspomagające uzyskiwanie faktur), jak i przyczynia się do wysychania w całej masie, niwelując tworzenie błony na powierzchni impastu. Większość zbadanych spoiw ma dobry wpływ na otrzymywanie grubych warstw, choć nie tak zdecydowanych. Powodem jest dodatek roztworów żywic manipulujących „płynięciem” farby, uniemożliwiając otrzymanie znacznych mas impastu. Wykazuja się dobra odpornością na spękania i odspojenia, ale również niską odpornością na zmiany barwy, czego powodem jest głównie użyty olej. Kilkudniowy czas wysychania może utrudniać pracę.

\section{Spoiwa olejne}

- nierozcieńczalne w wodzie:

- Impast nr $33^{45}$ (olej makowy (firmy Maimeri), $15 \mathrm{~cm}^{3}$ bieli tytanowej)

- Impast nr 34 (olej orzechowy (firmy Maimeri), $15 \mathrm{~cm}^{3}$ bieli tytanowej)

- Impast nr 35 (olej lniany (firmy Talens), wosk pszczeli w olejku terpentynowym $1: 3,15 \mathrm{~cm}^{3}$ bieli tytanowej)

- Impast nr 36 (olej makowy (firmy Maimeri), wosk pszczeli w olejku terpentynowym $1: 3,15 \mathrm{~cm}^{3}$ bieli tytanowej)

44 Ibidem, s. 178.

45 Wszystkie składniki spoiw techniki olejnej zostały dobrane przez autorkę na podstawie informacji z literatury. 
Wszystkie spoiwa nadają się do malarstwa impastowego, z możliwością kreowania różnych faktur, czemu sprzyja dodatek kredy i piasku. Warstwa malarska charakteryzuje się bardzo dobrą przyczepnościa do wszystkich rodzajów podłoża ze względu na wysoką elastyczność spoiwa. Impasty nie wykazuja tendencji do spękań. Aby rozprowadzanie farby zarówno pędzlem, jak i szpachlą było korzystniejsze dla osiagnięcia ciekawszych faktur, zaleca się przy tworzeniu farby umiarkowane dodawanie do pigmentu spoiwa, zwłaszcza oleju makowego (Impast nr 33 i 30), powodującego zbyt rzadką konsystencję. Wadą spoiwa olejnego jest zdolność tworzenia cienkiej warstwy linoksydu na powierzchni, stąd wysoki impast, naniesiony w jednej warstwie, nie wysycha w całej masie. Może to doprowadzić do długotrwałego czasu utrzymywania się miękkości farby pod zestaloną błoną. Kolejną niekorzystną cechą jest długi czas schnięcia konkretny dla poszczególnego typu oleju - na przykład olej makowy wysycha najdłużej. Badanie pokazało, że można ten czas skrócić poprzez odsączenie spoiwa na papierze (co jest częsta praktyką wśród artystów) lub połączenie farby z kredą albo piaskiem. $2 \%$ dodatek wosku powoduje szybsze zestalenie się farb, lecz nie poprawia wyraźnie schnięcia. Wszystkie impasty maja powierzchnię połyskliwa, która matowi się po zmieszaniu z kreda, po odsączeniu nadmiaru oleju lub niewielkim dodatkiem wosku. Zmniejszenie ilości oleju w trakcie ucierania farb również korzystnie wpływa na estetykę uzyskanych warstw. Spoiwo olejne dość szybko żółknie, co w szczególności ważne jest przy jasnych barwach. Badanie wykazało, że olej makowy jest najbardziej stabilnym optycznie spoiwem spośród użytych w części doświadczalnej. Technika olejna sprawdzi się, po odpowiednim przygotowaniu, do każdej metody malowania.

\section{Spoiwa woskowe}

- wodorozcieńczalne:

○ emulsja woskowa - typu ,olej w wodzie” - Impast nr $37^{46}(2$ cz. obj. wosku pszczelego (1:2 w olejku terpentynowym), 3 cz. obj. żółtka, 2 cz. obj. wody do rozcieńczenia, $15 \mathrm{~cm}^{3}$ bieli tytanowej)

\footnotetext{
46 Spoiwo to nadaje się do techniki pastoso, za: L. Losos, op. cit., s. 70.
} 
- Impast nr 38 ${ }^{47}$ (1,5 cz. obj. gumy arabskiej (gotowy roztwór gumy arabskiej firmy Winsor\&Newton), 1 cz. obj. wosku pszczelego, $1 \mathrm{cz}$. obj. werniksu damarowego (firmy Renesans), 8-10 cz. obj. goracej przegotowanej wody, $15 \mathrm{~cm}^{3}$ bieli tytanowej) (Il. 13-14A)

Spoiwa te nadają się do uzyskiwania impastów niskich i delikatnych wyłącznie na zaprawie „chudej”. Elastyczność impastów jest niewystarczająca do podobrazia płóciennego - pękaja z wyraźną tendencją do odspojeń na zaprawie „tłustej”. Konsystencja farb przypomina gęstą śmietanę. Nie zaleca się zagęszczania kredą, gdyż później warstwa malarska łatwo pęka. Farba o spoiwie z dodatkiem żółtka - Impast nr 37, nie nadaje się do wysokich impastów - jest zbyt mało elastyczna. Lepszymi właściwościami wykazała się farba o spoiwie $z$ dodatkiem gumy arabskiej i werniksu damarowego (Impast nr 38). Tę farbę również należy nakładać na „chudą” zaprawę. Werniks spowodował większy połysk powierzchni impastów. Farby nadaja się do malarstwa zamaszystego, a charakterystyczna konsystencja wspomaga szybkie nakładanie większych powierzchni za pomocą mniejszego udziału farby. Dużym atutem jest brak wyraźnych zmian optycznych w warstwie malarskiej, jak i krótki czas wysychania.

- nierozcieńczalne w wodzie:

- emulsja woskowa - typu „woda w oleju” - Impast nr 39 (1 cz. obj. wosku pszczelego, 1 cz. obj. terpentyny weneckiej, biel tytanowa olejna (olej lniany firmy Renesans, $15 \mathrm{~cm}^{3}$ bieli tytanowej)) (Il. 25-26A)

- $\underline{\text { Impast nr } 40^{48}}(1 \mathrm{cz}$. obj. wosku pszczelego, $1 \mathrm{cz}$. obj. oleju lnianego (firmy Renesans), biel tytanowa olejna (olej lniany firmy Renesans, $15 \mathrm{~cm}^{3}$ bieli tytanowej))

- Impast nr $41^{49}$ (1 cz. obj. oleju lnianego (firmy Renesans), 1 cz. obj. wosku pszczelego, 1 cz. obj. olejku terpentynowego, $15 \mathrm{~cm}^{3}$ bieli tytanowej))

47 B. Slanský, op. cit., s. 247.

48 Stephenson zaleca spoiwo do impastów, za: J. Stephenson, op. cit., s. 49.

49 Spoiwem tym posługiwał się William Hunt, za: S. Hackney, Paint and Purpose..., s. 82. 
Spoiwa te wykazują bardzo dobre cechy do malarstwa wykorzystującego wysokie, nakładane w jednej warstwie impasty. Elastyczność farb jest na tyle duża, że można swobodnie budować impasty na podobraziach płóciennych na wszystkich rodzajach zapraw. Różnice pojawiają się w konsystencjach uzyskanych farb, dyktujących odmienne sposoby pracy na podobraziach. Farba o spoiwie opartym na równej części wosku i oleju - Impast nr 40 - charakteryzuje się konsystencja przypominająca masło, co utrudnia zamaszyste działanie malarskie pędzlem i szpachlą. Wymaga wtedy dodatku piasku ułatwiającego lepszą kontrolę w nakładaniu. Najlepsze cechy do uzyskiwania wysokich warstw w formie różnorodnych faktur wykazuja przykłady Impastón nr $39 i 41$. W pierwszym przypadku medium z wosku i terpentyny weneckiej powodowało szybkie gęstnienie farby, co w rezultacie wymagało delikatnego rozcieńczania olejkiem terpentynowym, aby posługiwanie się pędzlem było swobodniejsze. Tutaj szpachla nadawała się najlepiej. Z kolei farba Impastu 41, której spoiwo oparte było na dodatku do wosku oleju i terpentyny weneckiej, charakteryzowała się najlepszymi cechami przydatnymi do malarstwa ekspresji. Łączenie z kredą i piaskiem polepsza właściwości farb. Nie zaobserwowano wyraźnych zmian barwy. Wadą spoiw woskowych, podczas łączenia z pigmentem, jest szybkie tężenie. W pracy malarskiej przydatny jest dość różnorodny, ale krótki czas wysychania farby - od kilku godzin do 1,5 dnia.

\section{Spoiwa oparte na żywicach sztucznych}

- wodorozcieńczalne:

- dyspersja akrylowa - Impast nr 42 (dyspersja akrylowa ${ }^{50}$ (firmy Blik), $15 \mathrm{~cm}^{3}$ bieli tytanowej) (Il. 15-16A)

- Impast nr 43 (1 cz. obj. dyspersji akrylowej (firmy Blik), 1 cz. obj. wody, $15 \mathrm{~cm}^{3}$ bieli tytanowej)

- Impast nr 44 (1 cz. obj. dyspersji akrylowej (firmy Blik), 1 cz. obj. oleju lnianego (firmy Renesans), $15 \mathrm{~cm}^{3}$ bieli tytanowej)

\footnotetext{
50 Do impastu została wykorzystana dyspersja akrylowa Primal AC 33 (na bazie akrylanu etylu 60\%, metakrylanu metylu 30\%, metakrylanu etylu 10\%).
} 
Spoiwa nadaja się do malowania impastowo na wszystkich rodzajach zaprawy. Aby uzyskać dobrą spoistość, farby z samym spoiwem akrylowym wymagaja jego dużego dodatku. Im mniejszy objętościowy udział dyspersji w farbie, tym bardziej odporność na spękania i brak adhezji, zwłaszcza do zaprawy „tłustej” i „półtłustej”, maleje. Dotyczy to przede wszystkim spoiwa Impastu nr 43, w którym użyta dyspersja była rozcieńczona woda. Inaczej jest w przypadku farby Impastu $n r 44$, opartej na spoiwie z dodatkiem oleju. Konsystencja farb opartych na samym spoiwie akrylowym powoduje, że podczas nakładania szpachla , ucieka” spod narzędzia, utrudniając kontrolowane nakłady impastowe w szczególności na śliskiej powierzchni zaprawy „tłustej”. Wtedy najlepiej dodać kredę lub piasek, który ułatwia uzyskiwanie wysokich kontrolowanych faktur impastu. Najlepszą konsystencję maja farby oparte na emulsji akrylowo-olejnej (Impast nr 44), wspomagajacej ekspresyjne nakładania grubych warstw wraz z zachowaniem śladu narzędzia. Spoiwa te cechuje stabilność optyczna, jak i szybki czas schnięcia, pomijając przypadek Impastu nr 44 - wykazującego się żółknięciem i wydłużonym czasem schnięcia do ok. 1,5 dnia.

- dyspersja akrylowa $\mathrm{z}$ dodatkiem gotowej pasty do impastu Impast nr 46 (Impasto Gel. Matt (gotowa pasta do impastów firmy Daler-Rowney), dyspersja akrylowa (Primal AC 33, firmy Blik), $15 \mathrm{~cm}^{3}$ bieli tytanowej)

- Impast nr 46A (Impasto Gel. Matt (gotowa pasta do impastów firmy Daler-Rowney), 1 cz. obj. dyspersji akrylowej (Primal AC 33, firmy Blik), 1 cz. obj. wody, $15 \mathrm{~cm}^{3}$ bieli tytanowej)_

- Impast nr 47 (Heary gel medium (gotowa pasta do impastów firmy Amsterdam), dyspersja akrylowa (Primal AC 33 firmy Blik), $15 \mathrm{~cm}^{3}$ bieli tytanowej)_

Pasty w nieznaczny sposób zagęściły farby o spoiwie akrylowym. Pomimo tego charakterystyczne „ślizganie się" farby na zaprawie „tłustej” pozostało, jak i niewygodne zjawisko „uciekania” spod narzędzia. Badanie wykazało, że dodatek pasty znacznie polepsza właściwości farby opartej na spoiwie rozcieńczonej dyspersji wodnej - nie pęka i charakteryzuje się dobrą adhezją do trzech typów zapraw. W celu zagęszczenia farby najlepiej dodać kredy. Ilość piasku należy zmniejszyć do minimum z powodu niewygodnego nakładania. 
- emulsja żółtkowa - typu „olej w wodzie” z dodatkiem gotowej past do impastu - Impast nr 48 (Heavy gel medium (gotowa pasta do impastów firmy Amsterdam), farba temperowa (1 cz. obj. żółtka, 1 cz. obj. oleju lnianego sykatywowanego, $15 \mathrm{~cm}^{3}$ bieli tytanowej)) (Il. 17-18A)

W przypadku farby Impastu nr 10 opartej na spoiwie wodorozcieńczalnym zmieszanie z pasta przeznaczona do farb wodnych (ta sama użyta została w Impaście 47) spowodowało polepszenie właściwości potrzebnych do uzyskiwania wysokich, o dobrej adhezji i spoistości w jednej warstwie impastów, podczas gdy badanie przypadku Impastu nr 10 wykazało przydatność jego spoiwa tylko do niższych warstw. Zestawienie Impastu nr 10 z. Impastem n 48 wyłania kolejna zależność w badaniu czasu wysychania: warstwa malarska Impastu nr 48 wysychała szybciej o połowę czasu schnięcia farby Impastu nr 10. Wypełniacz kredowy wyostrzył dukt pędzla, a piasek umożliwił otrzymanie ciekawej faktury. Nie zaobserwowano zmian optycznych.

- nierozcieńczalne w wodzie:

- żywica epoksydowa - Impast nr 45 (1 cz. obj. żywicy epoksydowej $^{51}$ (po połączeniu z utwardzaczem w stosunku 3:1, firmy Bresciani), $1 \mathrm{cz}$. oleju lnianego (firmy Renesans), $15 \mathrm{~cm}^{3}$ bieli tytanowej) (Il. 27-28A)

Spoiwo to nadaje się do otrzymywania wysokich impastów, bez zmian w pierwotnie uformowanej masie na trzech typach zapraw. Atutem takich spoiw jest znany czas wysychania, dyktowany przez utwardzacz. Należy znać czas wiazzania żywicy, aby zaplanować moment łączenia z olejem. Farba jest na tyle gęsta, że możliwe jest uzyskiwanie warstw grubych z zatrzymaniem w masie śladu użytego narzędzia. Należy unikać jednak przy takiej konsystencji dodawania kredy, gdyż znacznie utrudnia to swobodne nanoszenie pędzlem. Dodatek piasku umożliwił osiagnięcie wypukłych faktur. Impasty nie są stabilne optycznie, najprawdopodobniej z powodu dodatku oleju. Wymagane jest korzystanie z możliwie lepszych olejów, a w szczególności trwalszych żywic epoksydowych, aby naturalne starzenie żywicy nastąpiło w jak najpóźniejszym czasie.

51 Do wykonania Impastu nr 45 wykorzystano żywicę epoksydową Eurostac EP-IN 2501 i utwardzacz Eurostac 3503, firma Bresciani. 
- spoiwo olejne z dodatkiem gotowej pasty do impastów - Impast nr 49 (Medio di impasto (gotowa pasta do impastów firmy Maimeri), olej lniany gotowany, $15 \mathrm{~cm}^{3}$ bieli tytanowej).

Dodatek gotowej pasty do farby olejnej (Impast nr 49) zagęszcza ja, dzięki czemu można osiągnąć różnorodne efekty. Nie zaobserwowano zmian optycznych, oprócz Impastu nr 49 - prawdopodobnie spowodowanych użytym olejem w spoiwie farby olejnej lub jakością składników gotowej pasty.

\section{Podsumowanie wyników analiz}

W toku przeprowadzonych doświadczeń stwierdzono, że do impastów na podobraziach płóciennych najlepiej sprawdziły się spoiwa, spośród spoiw wodorozcieńczalnych (tab. I), akrylowe i emulsja akrylowo-olejna, również farby na bazie spoiwa akrylowego i emulsji żółtkowej z dodatkiem gotowych past do impastów. Z powodzeniem nadają się do otrzymywania wysokich warstw malarskich. W delikatnych, niskich impastach sprawdza się również spoiwa kazeinowe, emulsje żółtkowe.

Najlepiej przystosowanymi spoiwami do impastów są spoiwa nierozcieńczalne w wodzie (tab. II). W większości przypadków (oprócz emulsji żółtkowej, przydatnej jedynie w otrzymywaniu niskich impastów) wykazano dobre wyniki - spoiwa: kazeinowe, woskowe, olejno-żywiczne, olejne, na bazie żywic sztucznych nadaja się do uzyskiwania wysokich impastów nakładanych w jednej warstwie. 
Tabela I

\begin{tabular}{|c|c|c|c|c|c|}
\hline \multicolumn{6}{|c|}{ SPOIWA WODOROZCIEŃCZALNE } \\
\hline \multicolumn{3}{|c|}{ Spoiwa } & $\mathrm{Nr}$ & Wyniki & Wnioski \\
\hline \multirow{7}{*}{ 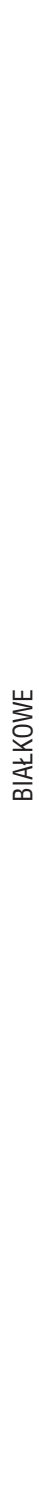 } & Klej glutynow & & $\begin{array}{l}1,1 \mathrm{~A} \\
2,2 \mathrm{~A}\end{array}$ & $\begin{array}{l}\text { Zła adhezja do zapraw, wysoka kruchość; spoiwo nie } \\
\text { nadaje się do wysokich warstw; dodatek strukturalny } \\
\text { polepsza adhezję; najlepsze wyniki z dodatkiem piasku } \\
\text { są na zaprawie „ttustej”; odradza się dodawania kredy, } \\
\text { która powoduje większą kruchość; szybki czas wysycha- } \\
\text { nia; odporność na zmiany barwne. }\end{array}$ & $\begin{array}{l}\text { Niezalecane do } \\
\text { impastów }\end{array}$ \\
\hline & \multirow{4}{*}{$\begin{array}{l}\text { Na bazie } \\
\text { jaja kurzego }\end{array}$} & żółtko jaja & 7 & $\begin{array}{l}\text { Zła adhezja do zapraw i tendencja do kruszenia, lepsze } \\
\text { wyniki przyczepności wykazuje próba z wypełniaczem } \\
\text { strukturalnym; rzadka konsystencja eliminuje wyso- } \\
\text { kie warstwy impastu; spoiwo stabilne optycznie; szyb- } \\
\text { ki czas wysychania. }\end{array}$ & $\begin{array}{l}\text { Niezalecane do } \\
\text { wysokich impa- } \\
\text { stów, do niskich } \\
\text { tak }- \text { z wypełnia- } \\
\text { czem struktural- } \\
\text { nym }\end{array}$ \\
\hline & & Białko jaja & $\begin{array}{l}8 \\
9\end{array}$ & $\begin{array}{l}\text { Tendencja do odspojeń na zaprawach, właściwość tę } \\
\text { można polepszyć dodatkiem strukturalnym, kreda zwięk- } \\
\text { sza kruchość; spoiwo stabilne optycznie o szybkim cza- } \\
\text { sie wysychania. }\end{array}$ & $\begin{array}{l}\text { Niezalecane do } \\
\text { wysokich impa- } \\
\text { stów, do niskich } \\
\text { tak }- \text { z dodatkiem } \\
\text { wypełniacza struk- } \\
\text { turalnego }\end{array}$ \\
\hline & & Całe jajo & 14 & $\begin{array}{l}\text { Zła adhezja do zapraw; kruchość farby; gęsta konsy- } \\
\text { stencja utrudnia rozprowadzanie pędzlem; szybki czas } \\
\text { wysychania i odporność na zmiany optyczne. }\end{array}$ & $\begin{array}{l}\text { Niezalecane do } \\
\text { impastów }\end{array}$ \\
\hline & & $\begin{array}{l}\text { Emulsja } \\
\text { żółtkowa }\end{array}$ & $\begin{array}{l}10 \\
11\end{array}$ & $\begin{array}{l}\text { Spoiwo impastu } 10 \text { nie nadaje się do wysokich impa- } \\
\text { stów; zła adhezja i kruchość. Spoiwo nr } 11 \text { - dobra ad- } \\
\text { hezja i spoistość masy. Maślana konsystencja powodu- } \\
\text { je ograniczenie w uzyskiwaniu wysokich warstw - do- } \\
\text { datek kredy umożliwia piętrzenie wyższych impastów; } \\
\text { konsystencja wspomaga uzyskiwanie ciekawych mate- } \\
\text { rii impastu; wszystkie impasty mają dobry czas wysy- } \\
\text { chania. Spoiwa nr } 10 \text { i } 11 \text { nie są odporne na zmia- } \\
\text { ny barwne. }\end{array}$ & $\begin{array}{l}\text { Zalecane tylko } \\
\text { spoiwo nr } 11 \text { do } \\
\text { niewysokich im- } \\
\text { pastów. Spoiwo } \\
10 \text { nie nadaje się } \\
\text { do impastów }\end{array}$ \\
\hline & \multirow{2}{*}{$\begin{array}{l}\text { Na bazie } \\
\text { kleju } \\
\text { kazeinowego }\end{array}$} & $\begin{array}{l}\text { Klej } \\
\text { kazeinowy }\end{array}$ & $\begin{array}{l}18 \\
19 \\
21\end{array}$ & $\begin{array}{l}\text { Im więcej spoiwa, tym większa odporność na kruszenie. } \\
\text { Najlepsza adhezja na zaprawie „chudej”. Dodatek kre- } \\
\text { dy i piasku powodował szybkie odspajanie. Dość rzad- } \\
\text { ka konsystencja utrudnia swobodne rozprowadzanie far- } \\
\text { by w postaci impastów; odporne na zmiany optyczne; } \\
\text { dobry czas wysychania. }\end{array}$ & $\begin{array}{l}\text { Zalecane do ni- } \\
\text { skich, delikatnych } \\
\text { impastów }\end{array}$ \\
\hline & & $\begin{array}{l}\text { Emulsja } \\
\text { kazeinowa }\end{array}$ & $\begin{array}{l}17 \\
23\end{array}$ & $\begin{array}{l}\text { Zła adhezja; im więcej spoiwa, tym lepsza trwałość im- } \\
\text { pastów; rzadka konsystencja utrudnia piętrzenie impa- } \\
\text { stów; szybki czas wysychania i odporność na zmiany } \\
\text { barwne. }\end{array}$ & $\begin{array}{l}\text { Zalecane do ni- } \\
\text { skich i delikat- } \\
\text { nych impastów }\end{array}$ \\
\hline
\end{tabular}


Tabela I cd.

\begin{tabular}{|c|c|c|c|c|c|}
\hline \multicolumn{6}{|c|}{ SPOIWA WODOROZCIEŃCZALNE } \\
\hline \multicolumn{3}{|c|}{ Spoiwa } & \multirow{2}{*}{$\begin{array}{c}\mathrm{Nr} \\
\text { impastu } \\
4\end{array}$} & \multirow{2}{*}{\begin{tabular}{|l|}
\multicolumn{1}{|c|}{ Wyniki } \\
Najlepszą adhezją charakteryzują się impasty na zapra- \\
wie „tłustej”, szybki czas wysychania i odporność na \\
zmiany optyczne.
\end{tabular}} & \multirow{2}{*}{\begin{tabular}{|l}
\multicolumn{1}{|c}{ Wnioski } \\
$\begin{array}{l}\text { Niezalecane do } \\
\text { impastów }\end{array}$
\end{tabular}} \\
\hline 岁 & & $\begin{array}{l}\text { Na bazie } \\
\text { gum } \\
\text { roślinnych }\end{array}$ & & & \\
\hline 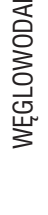 & $\begin{array}{l}\text { Na bazie } \\
\text { gum } \\
\text { roślinnych }\end{array}$ & $\begin{array}{l}\text { Emulsja } \\
\text { gumowa }\end{array}$ & $\begin{array}{l}3 \\
5 \\
6\end{array}$ & $\begin{array}{l}\text { Najlepsza adhezja impastów } 5 \text { i } 6 \text { na zaprawie „tłustej”; } \\
\text { impast nr } 5 \text { nadaje się do impastów; należy ograniczyć } \\
\text { dodatek kredy; impast nr } 3 \text { - dobra adhezja tylko na za- } \\
\text { prawie „chudej”; spoiwo nr } 5 \text { cechuje dość dobra od- } \\
\text { porność na zmiany optyczne. }\end{array}$ & $\begin{array}{l}\text { Tylko spoiwo nr } 5 \\
\text { zalecane do śred- } \\
\text { niej wysokości } \\
\text { impastów. Spo- } \\
\text { iwa } 3 \text { i } 6 \text { - nieza- } \\
\text { lecane. }\end{array}$ \\
\hline 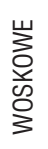 & Emulsja wosk & owa & $\begin{array}{l}37 \\
38\end{array}$ & $\begin{array}{l}\text { Najlepsza adhezja na zaprawie „chudej”; tendencja } \\
\text { do kruszenia i odspojeń; dobra odporność na zmiany } \\
\text { barwne i szybki czas wysychania }\end{array}$ & $\begin{array}{l}\text { Nie zaleca się do } \\
\text { impastów }\end{array}$ \\
\hline \multirow{4}{*}{ 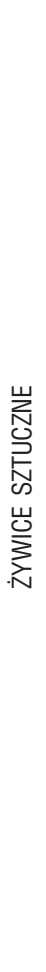 } & \multirow{4}{*}{$\begin{array}{l}\text { Na bazie } \\
\text { i z dodatkiem } \\
\text { żywicy akry- } \\
\text { lowej w po- } \\
\text { staci gotowej } \\
\text { pasty do im- } \\
\text { pastów }\end{array}$} & $\begin{array}{l}\text { Dyspersja } \\
\text { akrylowa }\end{array}$ & $\begin{array}{l}42 \\
43\end{array}$ & $\begin{array}{l}\text { Spoiwo nr } 42 \text { - dobra adhezja; brak tendencji do kru- } \\
\text { szenia; im więcej spoiwa, tym pewniejsza trwałość im- } \\
\text { pastów; dość rzadka konsystencja wymaga dodatku kre- } \\
\text { dy w celu zagęszczenia. Spoiwo nr } 43 \text { nie nadaje się } \\
\text { do impastów. Oba charakteryzują się dobrą odporno- } \\
\text { ścią na zmiany barwne i szybkim czasem wysychania. }\end{array}$ & $\begin{array}{l}\text { Spoiwo nr } 42 \text { za- } \\
\text { lecane do impa- } \\
\text { stów. Spoiwo } 43 \\
\text { - niezalecane do } \\
\text { impastów }\end{array}$ \\
\hline & & $\begin{array}{l}\text { Emulsja } \\
\text { akrylowo- } \\
\text {-olejna }\end{array}$ & 44 & $\begin{array}{l}\text { Dobra adhezja; brak tendencji do odspojeń; odpowied- } \\
\text { nia konsystencja wspomagająca piętrzenie wysokich im- } \\
\text { pastów; brak odporności na zmiany optyczne }\end{array}$ & $\begin{array}{l}\text { Zalecane do im- } \\
\text { pastów }\end{array}$ \\
\hline & & $\begin{array}{l}\text { Dysper- } \\
\text { sja akrylo- } \\
\text { wa + doda- } \\
\text { na do farby } \\
\text { gotowa pa- } \\
\text { sta do impa- } \\
\text { stów o spo- } \\
\text { iwie akrylo- } \\
\text { wym } \\
\end{array}$ & $\begin{array}{c}46 \\
46 \mathrm{~A} \\
47\end{array}$ & $\begin{array}{l}\text { Dobra adhezja; brak tendencji do spękań; konsysten- } \\
\text { cja półgęsta; można dodać kredy w celu zagęszczenia. } \\
\text { Gotowa pasta do impastów wyraźnie poprawiła właści- } \\
\text { wości farby o spoiwie akrylowym zmieszanym z wodą } \\
\text { w stosunku } 1: 1 \text { Impastu nr 43. Farbę cechuje dobra } \\
\text { adhezja, bez tendencji do spękań. Dobre właściwości } \\
\text { optyczne i szybki czas schnięcia. }\end{array}$ & $\begin{array}{l}\text { Zalecane do im- } \\
\text { pastów }\end{array}$ \\
\hline & & $\begin{array}{l}\text { Emulsja żółt- } \\
\text { kowa }+ \text { do- } \\
\text { dana do far- } \\
\text { by goto- } \\
\text { wa pasta do } \\
\text { impastów } \\
0 \text { spoiwie } \\
\text { akrylowym }\end{array}$ & 48 & $\begin{array}{l}\text { Do eksperymentu zostało użyte spoiwo Impastu nr } 10 . \\
\text { Po zmieszaniu farby z gotową pastą wyraźnie poprawi- } \\
\text { ła się adhezja do wszystkich rodzajów zapraw. Brak ten- } \\
\text { dencji do spękań; odporność na zmiany barwne. Do- } \\
\text { datek pasty uelastycznił farbę. Czas schnięcia zmniej- } \\
\text { szył się } 0 \text { ok. } 2 \text { h w porównaniu z czasem wysycha- } \\
\text { nia Impastu nr } 10 .\end{array}$ & $\begin{array}{l}\text { Zalecane do im- } \\
\text { pastów }\end{array}$ \\
\hline
\end{tabular}


Tabela II

\begin{tabular}{|c|c|c|c|c|c|}
\hline \multicolumn{6}{|c|}{ SPOIWA NIEROZCIEŃCZALNE W WODZIE } \\
\hline \multicolumn{3}{|c|}{ Spoiwa } & Nr impastu & Wyniki & Wnioski \\
\hline \multirow[t]{2}{*}{ 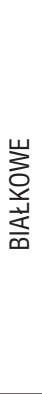 } & $\begin{array}{l}\mathrm{Na} \text { bazie } \\
\text { żółtka jaja }\end{array}$ & $\begin{array}{l}\text { Emulsja } \\
\text { żółtkowa }\end{array}$ & $\begin{array}{l}12 \\
13 \\
15 \\
16\end{array}$ & $\begin{array}{l}\text { Dobra adhezja i brak spękań w przypadku Impastów } 12 \\
\text { i 15. Impast } 16 \text { pękał i odspajał się. Wypełniacz struk- } \\
\text { turalny poprawiał adhezję Impastu 13, podczas gdy inne } \\
\text { próby wykazywały się niską elastycznością. Impasty } 13,15 \\
\text { i } 16 \text { wykazywały się dość dobrą odpornością na żółknię- } \\
\text { cie. Dobry czas schnięcia i konsystencja ułatwiająca pię- } \\
\text { trzenie impastów. }\end{array}$ & $\begin{array}{l}\text { Spoiwa nr } 12 \\
\text { i } 15 \text { zaleca- } \\
\text { ne do średniej } \\
\text { wysokości im- } \\
\text { pastów, } 16 \text { nie } \\
\text { nadaje się do } \\
\text { impastów }\end{array}$ \\
\hline & Kazeina & $\begin{array}{l}\text { Emulsja ka- } \\
\text { zeinowa }\end{array}$ & 22 & $\begin{array}{l}\text { Dobra adhezja i brak spękań. Brak wyraźnych zmian } \\
\text { optycznych i dość szybki czas schnięcia. Półgęsta konsy- } \\
\text { stencja, umożliwiająca malowanie ekspresyjne; kreda za- } \\
\text { gęszcza i umożliwia budowanie wyższych impastów. }\end{array}$ & $\begin{array}{l}\text { Zalecane } \\
\text { do impastów }\end{array}$ \\
\hline 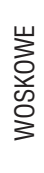 & \multicolumn{2}{|c|}{ Emulsja woskowa } & $39-41$ & $\begin{array}{l}\text { Dobra adhezja; brak spękań. Dobra odporność na zmiany } \\
\text { optyczne; gęsta konsystencja umożliwia uzyskiwanie wyso- } \\
\text { kich impastów. Czas schnięcia jest zróżnicowany - od kil- } \\
\text { ku godzin do kilku dni; im więcej składnika w postaci ole- } \\
\text { ju, tym czas schnięcia bardziej wydłużony. }\end{array}$ & $\begin{array}{l}\text { Zalecane } \\
\text { do impastów }\end{array}$ \\
\hline \multirow{2}{*}{ 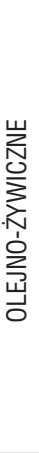 } & \multicolumn{2}{|c|}{$\begin{array}{l}\text { Na bazie spoiwa olejno- } \\
\text { żywicznego }\end{array}$} & $\begin{array}{c}24 \\
26-30\end{array}$ & $\begin{array}{l}\text { Dobra przyczepność do wszystkich badanych rodzajów za- } \\
\text { praw; brak spękań; długi czas wysychania - kilkudniowy; } \\
\text { niska odporność na zmiany barwy. Im więcej dodatku ży- } \\
\text { wicznego, tym farba wydaje się mniej gęsta. Dobre efek- } \\
\text { ty wykazuje próba z dodatkiem kredy, która matowi farbę } \\
0 \text { dość połyskliwej powierzchni i pozwala uzyskiwać wy- } \\
\text { sokie impasty. }\end{array}$ & $\begin{array}{l}\text { Zalecane } \\
\text { do impastów }\end{array}$ \\
\hline & \multicolumn{2}{|c|}{$\begin{array}{l}\text { Olejno-żywiczne medium } \\
\text { dodane do olejnej farby }\end{array}$} & $\begin{array}{l}25 \\
31 \\
32\end{array}$ & $\begin{array}{l}\text { Dobra przyczepność do podłoży i brak spękań. Ilością do- } \\
\text { dawanego medium można łatwiej manipulować konsysten- } \\
\text { cję farby. Dodatek kredy zagęszcza i matowi farbę, wchła- } \\
\text { nia część spoiwa. Żółknie i długo schnie. Zaprawa „chu- } \\
\text { da” i „półłłusta” może wchłaniać część spoiwa, powodu- } \\
\text { jąc matowienie i ślady wokół farby. }\end{array}$ & $\begin{array}{l}\text { Zalecane } \\
\text { do impastów }\end{array}$ \\
\hline \multicolumn{3}{|c|}{ OLEJNE } & $33-36$ & $\begin{array}{l}\text { Dobra adhezja i brak odspojeń; długi czas schnięcia; wraż- } \\
\text { liwość na żółknięcie; dobra konsystencja do budowania } \\
\text { trwałych impastów. Dodatek kredy powoduje zmatowie- } \\
\text { nie i wchłanianie części spoiwa, eliminując rozległe pla- } \\
\text { my spoiwa wokół impastów na zaprawach chudszych. Dłu- } \\
\text { gi czas schnięcia. }\end{array}$ & $\begin{array}{l}\text { Zalecane } \\
\text { do impastów }\end{array}$ \\
\hline \multirow{2}{*}{ 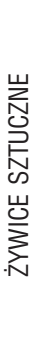 } & \multicolumn{2}{|c|}{$\begin{array}{l}\text { Spoiwo epoksydowo- } \\
\text { olejne }\end{array}$} & 45 & $\begin{array}{l}\text { Dobra adhezja na trzech rodzajach zaprawy; odporność na } \\
\text { spękania; spoiwo żółknie; czas schnięcia dość krótki. Far- } \\
\text { ba dobrze łączy się z wypełniaczami. Dodatek kredy po- } \\
\text { woduje szybkie gęstnienie, uniemożliwiając swobodną pra- } \\
\text { cę pędzlem, jedynie szpachlą. }\end{array}$ & $\begin{array}{l}\text { Zalecane } \\
\text { do impastów }\end{array}$ \\
\hline & \multicolumn{2}{|c|}{$\begin{array}{l}\text { Spoiwo olejne+dodana } \\
\text { do farby gotowa pasta } \\
\text { do impastów }\end{array}$} & 49 & $\begin{array}{l}\text { Dobra przyczepność; brak spękań. Pasta powoduje gęst- } \\
\text { nienie farby olejnej, przyspiesza proces schnięcia o ok. } 2 \\
\text { dni. Widoczne zźółknięcie. Dodatek obu wypełniaczy za- } \\
\text { gęszcza, powodując utrudnienia w swobodnym malowa- } \\
\text { niu pędzlem. }\end{array}$ & $\begin{array}{l}\text { Zalecane } \\
\text { do impastów }\end{array}$ \\
\hline
\end{tabular}


Spoiwa wodorozcieńczalne białkowe i węglowodanowe na bazie naturalnych produktów, takich jak: klej glutynowy, jajko kurze (zółtko, białko, całe jajo), kleje kazeinowe oraz gumy roślinne, jak i spoiwa woskowe nie są polecane do uzyskiwania wysokich impastów. Charakteryzują się złą adhezją do podłoża, tendencją do spękań i kruszenia. Dodatek w postaci piasku w większości przypadków poprawia właściwości farb. Kreda dodatkowo „odchudza” farby, powodując większe tendencje do odspojeń i spękań. Najlepszymi właściwościami do wysokich impastów spośród spoiw wodorozcieńczalnych wykazują się spoiwa na bazie dyspersji akrylowych (Impasty $n r$ 42, 44) i z użyciem gotowych past na bazie żywic akrylowych (Impast 46-48).

Spoiwa nierozpuszczalne w wodzie, białkowe na bazie produktów: żółtko i klej kazeinowy, tworzące z olejami emulsje typu „woda w oleju”, zalecane są do niskich impastów. Spoiwa na bazie wosku pszczelego (Impasty 39-41), spoiwa olejno-żywiczne (Impasty 24, 25, 27-32) i olejne (Impasty 33-36) wykazuja się najlepszymi właściwościami dla malarstwa impastowego, jak i spoiwa oparte na żywicach sztucznych - epoksydowe i akrylowe (Impasty 45 i 49). Wypełniacze: kreda i piasek, sprzyjaja uzyskiwaniu wysokich impastów, stabilizuja je i zagęszczają. Wadami tych spoiw jest: wrażliwość na żółknięcie, spowodowana składnikiem w postaci oleju oraz długi czas wysychania.

Zapoznanie się z charakterem każdego ze zbadanych spoiw może okazać się przydatne przede wszystkim dla artystów, którzy chcieliby zaznajomić się z różnymi technikami malarskimi i wykorzystać je we własnej twórczości. Zebrane informacje moga służyć również w pracach konserwatorskich poprzez zwrócenie uwagi na charakter użytych spoiw w impastach i wykorzystaniu tej wiedzy w uzupełnianiu ubytków warstwy malarskiej zabytkowych obrazów.

\section{Summary}

\section{The technology and technique of obtaining impasto on textile supports}

Painting with the use of impasto has been known for ages. Using a considerable amount of paint for aesthetic and artistic purpose requires certain knowledge 
which would protect the work of art from damage. The aim of the undertaken research was to define the usefulness of 49 self-chosen types of binders typical of a few painting techniques applied on textile support covered with mortar of various capacity to absorb (emulsion like 'water in oil' and 'oil in water', gaining the so called mortar 'slim', 'semi-fat' and 'fat'). A crucial aspect was to define the influence of the base on the quality of the painting texture. In order to enrich knowledge concerning possibilities of gaining impasto painting layer, the ability of easy application of paint having a different consistency: liquid and thick looking like 'paste' has been examined. Moreover, the quality of application and capability of spreading the paint with the use of a brush or a painting spatula has been studied. Additionally, two types of fillers: chalk and sand were added to the paint in order to acquire the desired form of impasto structure. Due to the purpose of using the research for the benefit of a contemporary artist and a conservator, as well as taking into consideration the complex nature of recipes found in literature, part of ingredients of binders has been modified and supplied with the ones accessible on the contemporary market. In the composition of binders of complex structure sets of a few binders can be found. They have been divided with regard to the type of the main binder and the capability to dilute and not dilute it with water ${ }^{52}$.

52 Artykul powstał na podstawie badań autorek, część z nich została zawarta w pracy magisterskiej A. Cwynar, Technologia i technika usyskiwania impastów na wybranych podobraziach płóciennych, wykonanej pod kierunkiem dr hab. Justyny Olszewskiej-Świetlik, prof. UMK, Zakład Technologii i Technik Malarskich UMK w Toruniu, Toruń 2012. 


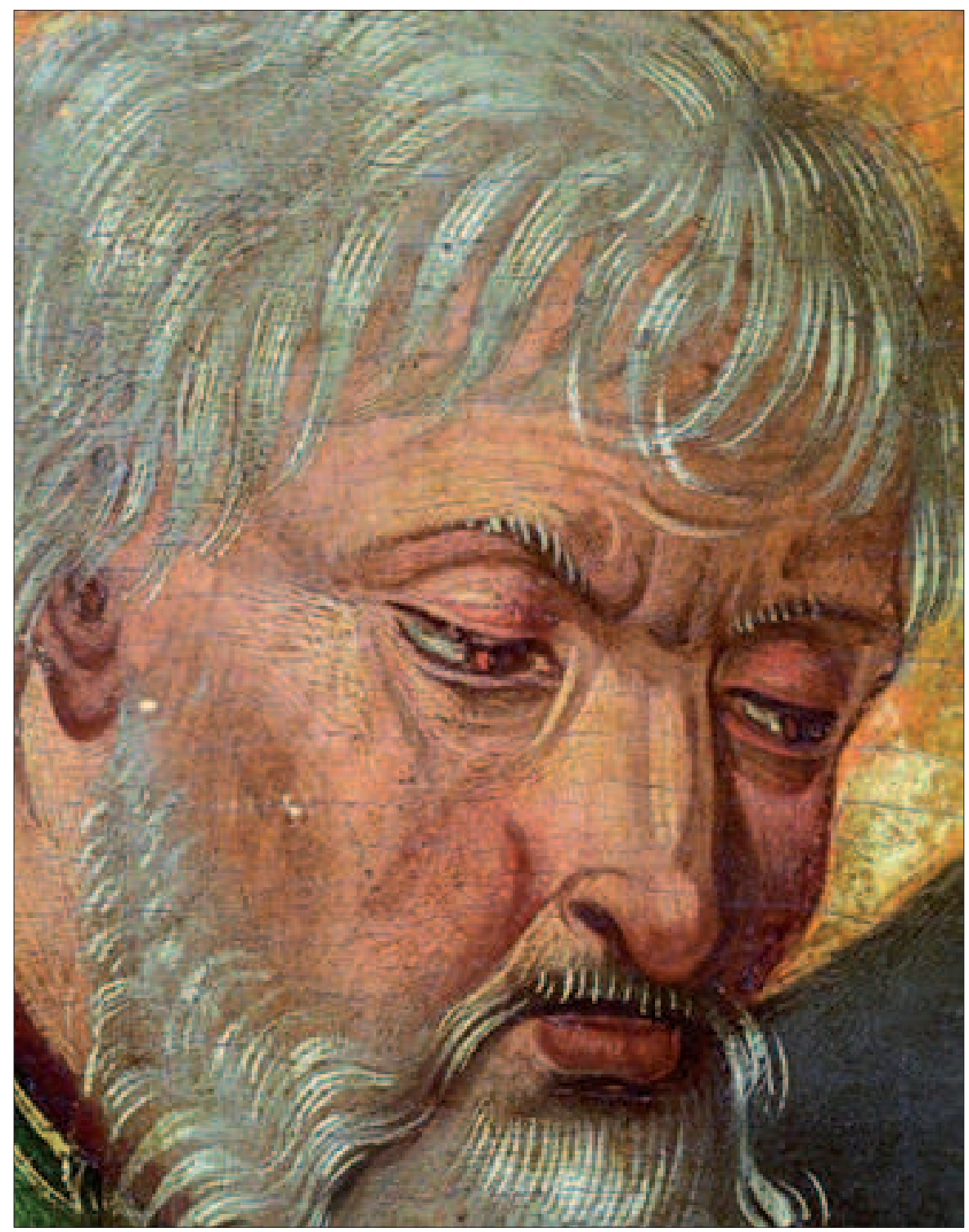

Il. 1. Przykład podkreślenia trójwymiarowości anatomii twarzy wysokim impastem wzdłuż nosa i w formie wysokiego pojedynczego dotknięcia na jego zakończeniu oraz impastem, nałożonym szeroko, w okolicy kącika oka. Fotografia fragmentu sceny Wniebowzięcie z kwatery uroczyste otwarcie - awers dawnej nastawy ołtarzowej z kościoła pw. św. św. Piotra i Pawła w Strzegomiu, tzw. Mistrz ołtarza ze Strzegomia, 1486/87, Muzeum Okręgowe w Toruniu (fot. A. Skowroński). 
[232]

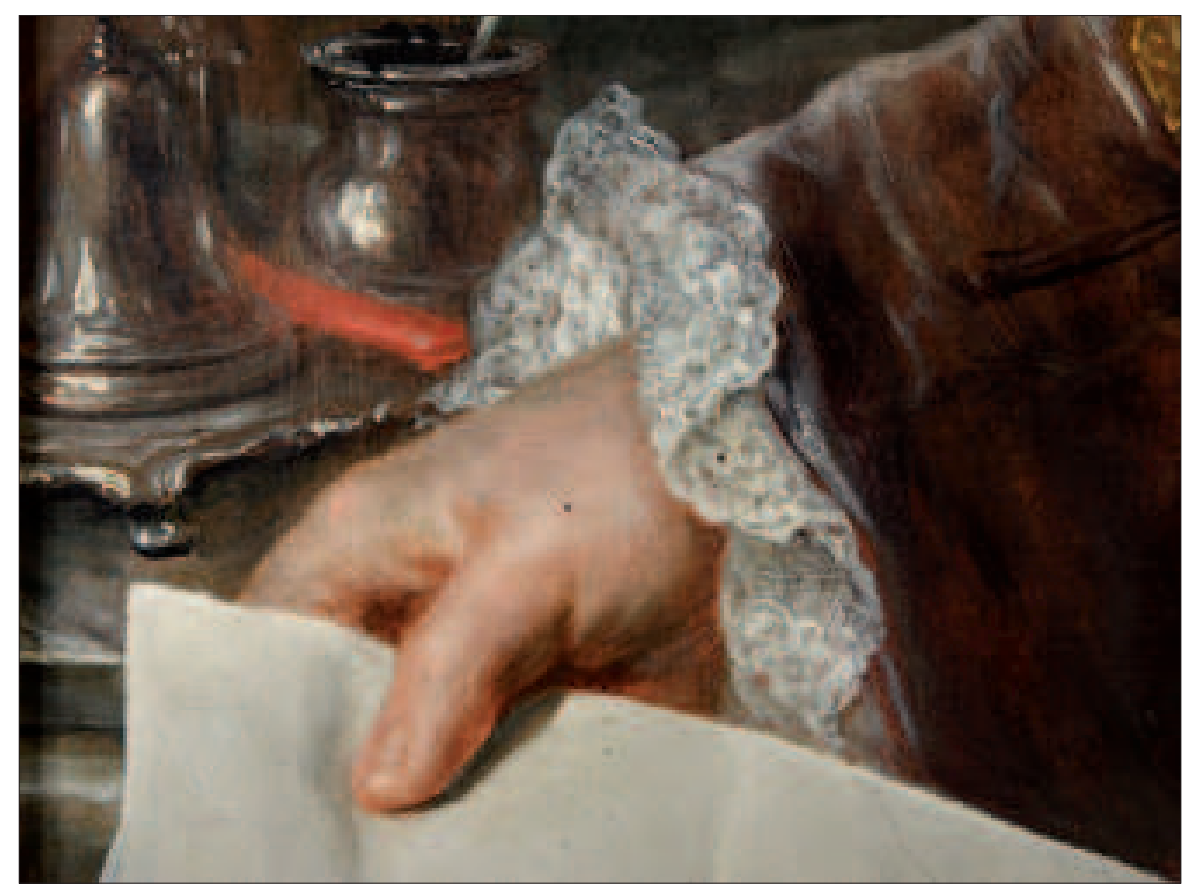

Il. 2. Przykład podkreślenia materii stroju przy wykorzystaniu impastu. Fragmentu obrazu Jacob Wessel (1710-1780), Portret Jacoba Theodora Kleina, 1759, Muzeum Narodowe w Gdańsku, olej na płótnie (fot. A. Skowroński) 


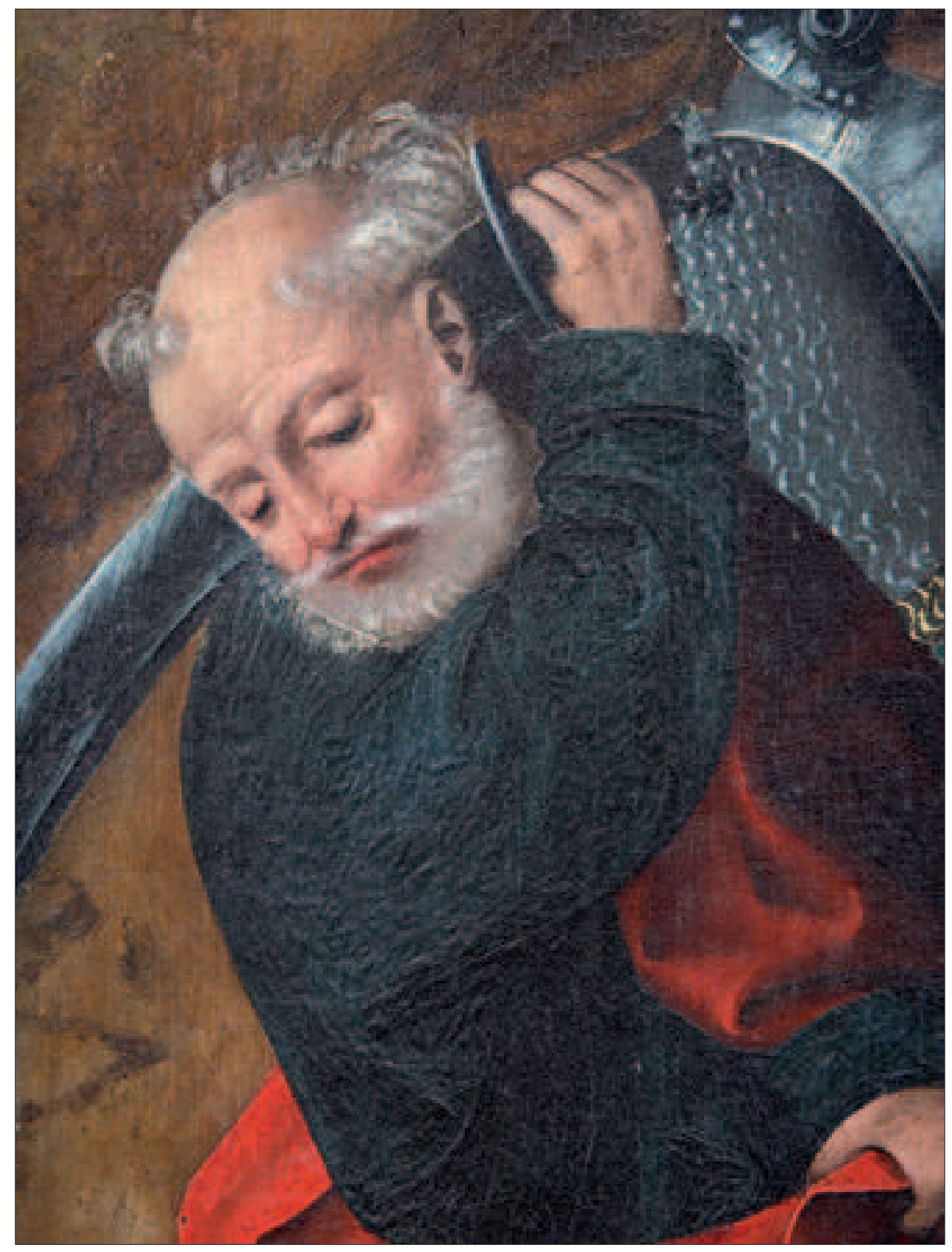

IL. 3. Przykład faktury malarskiej wynikającej z rodzaju zastosowanych materiałów malarskich. Błękitna szata opracowana farbą zawierająca gruboziarnisty naturalny azuryt. Fragment retabulum antwerpskiego z Bazyliki Mariackiej w Gdańsku nazywanego św. Adriana, ok. 1510 (fot. A. Skowroński) 


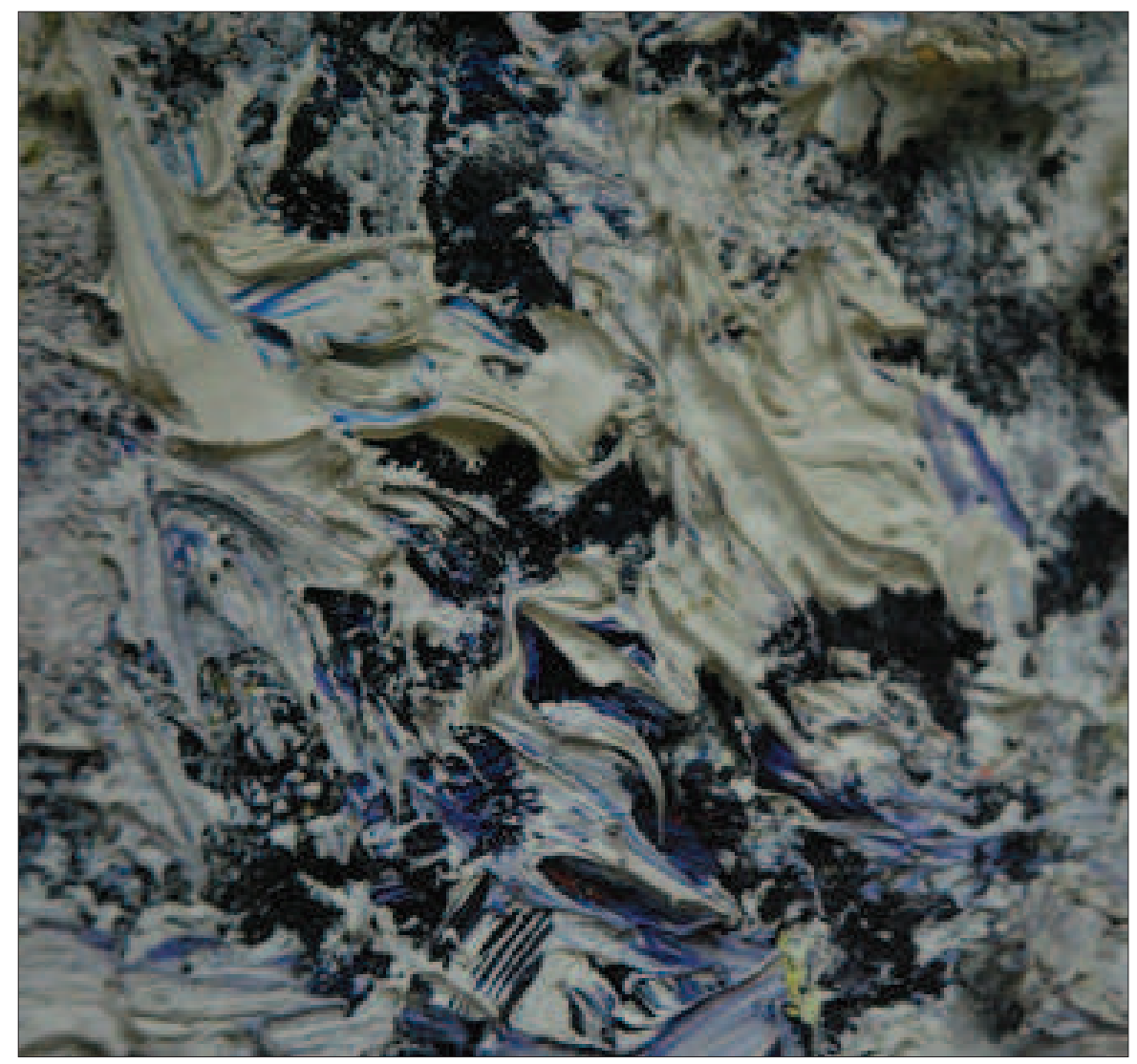

Il. 4. Fragment ekspresyjnie zbudowanej powierzchni obrazu za pomoca pędzli i szpachli, Lutka Pink (1906-1998), Arche saxe, 1958, technika olejna na płótnie, Muzeum Uniwersyteckie w Toruniu (fot. A. Cwynar) 

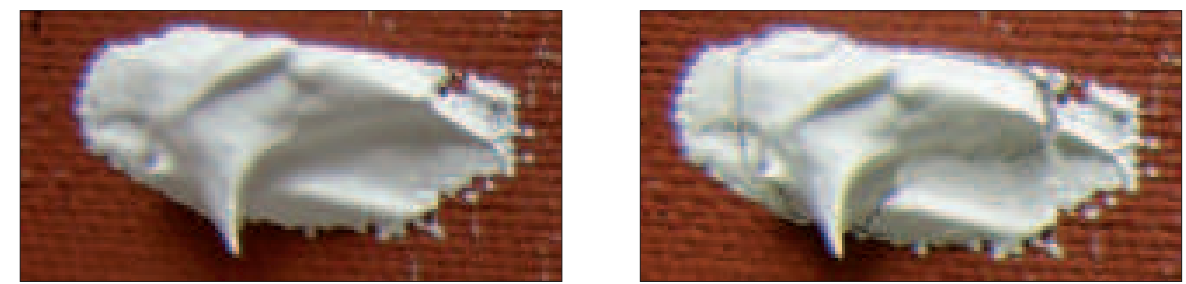

Il. 5, il. 5A. Przykład impastu na zaprawie „chudej” o spoiwie białkowym - wodorozcieńczalnym, na bazie kleju glutynowego (spoiwo $\mathrm{nr} 2 \mathrm{~A}: 1 \mathrm{cz}$. obj. farby temperowej $(1 \mathrm{cz}$. obj. żółtka jaja, 1 cz. obj. oleju gotowanego, $15 \mathrm{~cm} 3$ bieli tytanowej), 0,25 cz. obj. 5\% kleju skórnego). Il. 5 - wygląd impastu bezpośrednio po nałożeniu, $5 \mathrm{~A}$ - po upływie 6 tygodni - zauważalne zniszczenia w postaci spękań i odspojeń (fot. A. Cwynar)
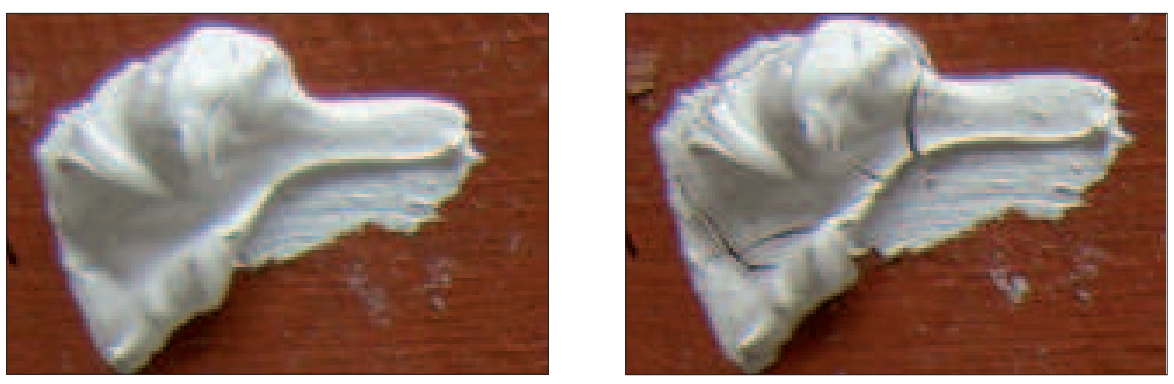

Il. 6, il. 6A. Przykład impastu, próby 2 - o rzadszej konsystencji, na zaprawie „tłustej” o spoiwie białkowym - wodorozcieńczalnym, na bazie kleju glutynowego (spoiwo nr 2A: $1 \mathrm{cz}$. obj. farby temperowej (1 cz. obj. żółtka jaja, $1 \mathrm{cz}$. obj. oleju gotowanego, $15 \mathrm{~cm}^{3}$ bieli tytanowej), 0,25 cz. obj. 5\% kleju skórnego). Il. 6 - wygląd impastu bezpośrednio po nałożeniu, $6 \mathrm{~A}$ - po upływie 6 tygodni - zauważalne zniszczenia w postaci spękań (fot. A. Cwynar)
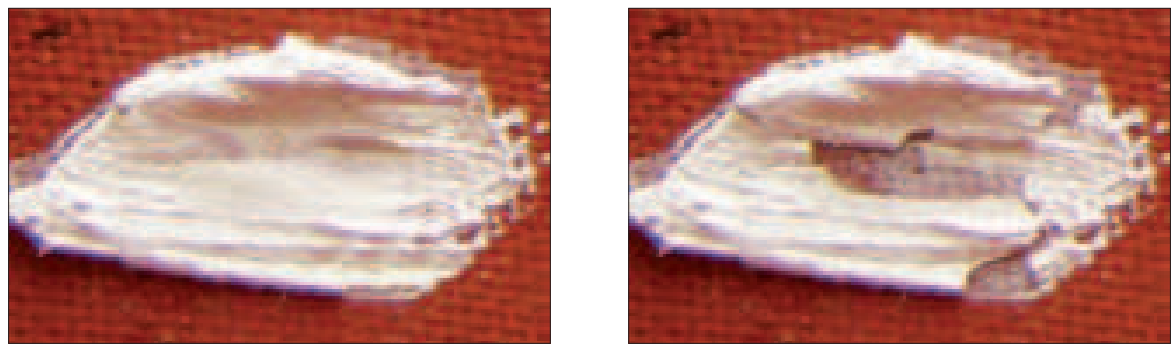

Il. 7, il. 7A. Przykład impastu na zaprawie „chudej” o spoiwie białkowym - wodorozcieńczalnym, na bazie jaja kurzego (spoiwo nr 9: ${ }^{1 / 4} \mathrm{cz}$. obj. roztworu ałunu (1:10 w wodzie), 1 cz. obj. białka, $1 / 3$ cz. obj. $10 \%$ żywicy mastyksowej w olejku terpentynowym, $15 \mathrm{~cm}^{3}$ bieli tytanowej). Il. 7 - wygląd impastu bezpośrednio po nałożeniu, 7A - po upływie 6 tygodni - zauważalne zniszczenia w postaci spękań i odspojeń (fot. A. Cwynar) 

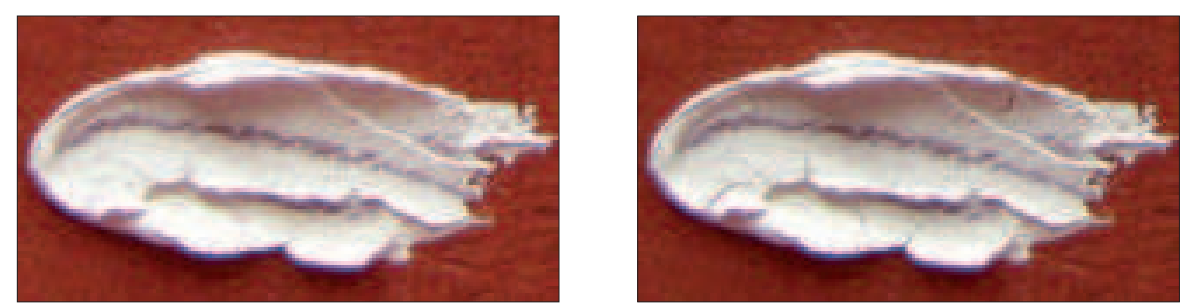

Il. 8, il. 8A. Przykład impastu nakładanego szpachla, na zaprawie „tłustej” o spoiwie białkowym - wodorozcieńczalnym, na bazie jaja kurzego (spoiwo nr 9: 1/4 cz. obj. roztworu ałunu (1:10 w wodzie), 1 cz. obj. białka, $1 / 3$ cz. obj. $10 \%$ żywicy mastyksowej w olejku terpentynowym, $15 \mathrm{~cm}^{3}$ bieli tytanowej). Il. 8 - wygląd impastu bezpośrednio po nałożeniu, $8 \mathrm{~A}$ - po upływie 6 tygodni - zauważalne zniszczenia w postaci spękań w grubszych partiach impastu (fot. A. Cwynar)
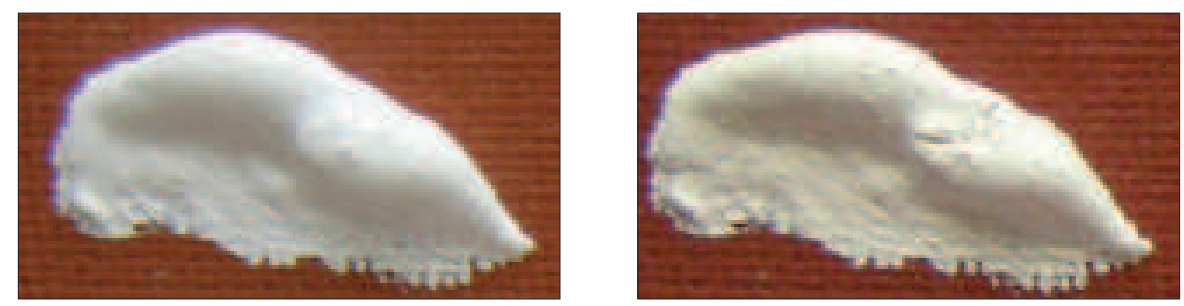

Il. 9, il. 9A. Przykład impastu na zaprawie „chudej” o spoiwie białkowym - wodorozcieńczalnym, na bazie kleju kazeinowego (spoiwo nr 18: 1 cz. obj. roztworu kazeiny, 1 cz. obj. olejku terpentynowego, $1 \mathrm{cz}$. obj. terpentyny weneckiej, $15 \mathrm{~cm}^{3}$ bieli tytanowej). Il. 9 - wygląd impastu bezpośrednio po nałożeniu, $9 \mathrm{~A}$ - po upływie 6 tygodni - zauważalne niewielkie zniszczenia w postaci spękań w najgrubszych partiach impastu (fot. A. Cwynar).
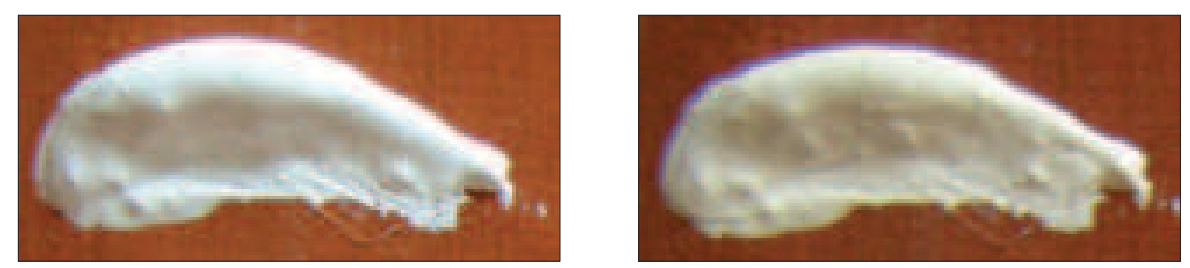

Il. 10, il. 10A. Przykład impastu na zaprawie „tłustej” o spoiwie białkowym - wodorozcieńczalnym, na bazie kleju kazeinowego (spoiwo nr 18: 1 cz. obj. roztworu kazeiny, $1 \mathrm{cz}$. obj. olejku terpentynowego, $1 \mathrm{cz}$. obj. terpentyny weneckiej, $15 \mathrm{~cm}^{3}$ bieli tytanowej). Il. 10 - wygląd impastu bezpośrednio po nałożeniu, 10A - po upływie 6 tygodni - zauważalne niewielkie zniszczenia w postaci spękań w najgrubszych partiach impastu (fot. A. Cwynar). 

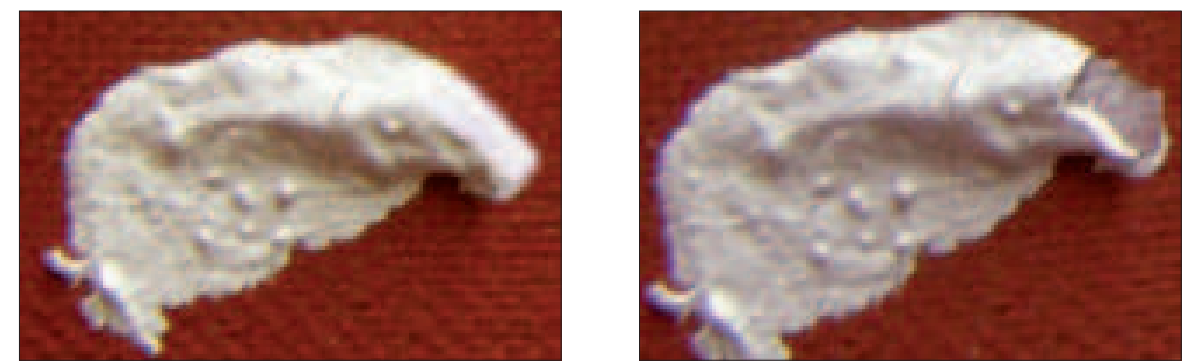

Il. 11, il. 11A. Przykład impastu na zaprawie „chudej” o spoiwie weglowodanowym - wodorozcieńczalnym, na bazie gum roślinnych (spoiwo nr 5: 5 cz. obj. roztworu gumy arabskiej (1:2), $1 \mathrm{cz}$. obj. oleju lnianego (firmy Renesans), $1 \mathrm{cz}$. obj. werniksu damarowego (roztwór żywicy damarowej w terpentynie 1:2), 4 cz. obj. gliceryny, $15 \mathrm{~cm}^{3}$ bieli tytanowej). Il. 11 - wygląd impastu bezpośrednio po nałożeniu, 11A - po upływie 6 tygodni - zauważalne zniszczenia w postaci odspojeń w najgrubszych partiach impastu (fot. A. Cwynar)
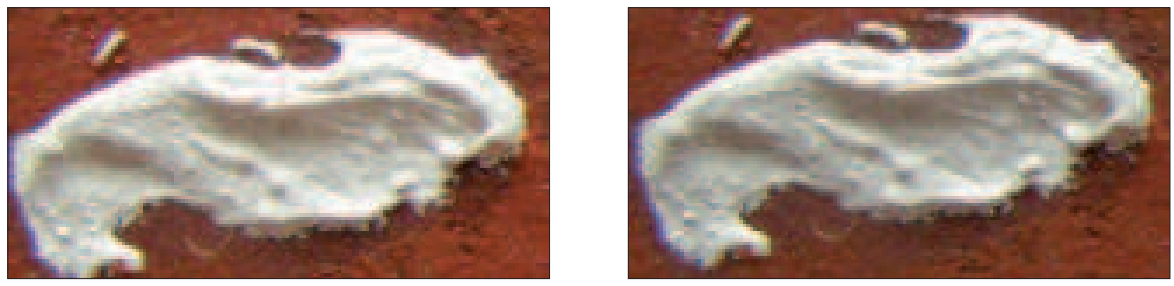

Il. 12, il. 12A. Przykład impastu na zaprawie „tłustej” o spoiwie węglowodanowym - wodorozcieńczalnym, na bazie gum roślinnych (spoiwo nr 5: 5 cz. obj. roztworu gumy arabskiej (1:2), 1 cz. obj. oleju lnianego (firmy Renesans), 1 cz. obj. werniksu damarowego (roztwór żywicy damarowej w terpentynie 1:2), 4 cz. obj. gliceryny, $15 \mathrm{~cm}^{3}$ bieli tytanowej). Il. 12 - wygląd impastu bezpośrednio po nałożeniu, 12A - po upływie 6 tygodni - zauważalne zniszczenia w postaci delikatnych spękań (fot. A. Cwynar)
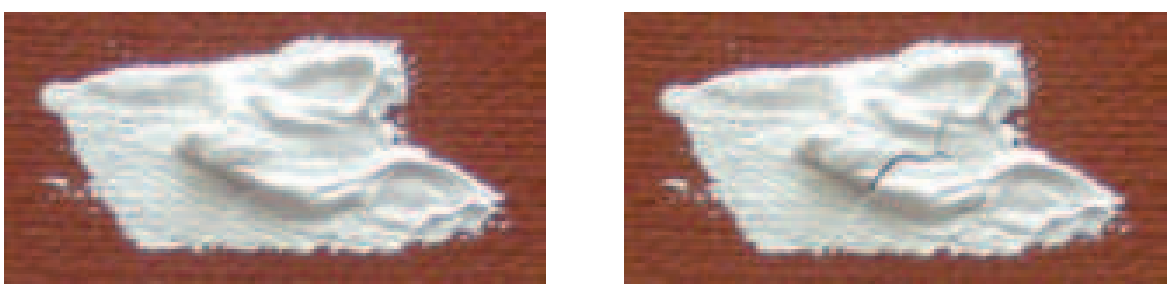

Il. 13, il. 13A. Przykład impastu na zaprawie „półtłustej” o spoiwie woskowym - wodorozcieńczalnym (spoiwo nr 38: 1,5 cz. obj. gumy arabskiej (gotowy roztwór gumy arabskiej firmy Winsor\&Newton), 1 cz. obj. wosku pszczelego, 1 cz. obj. werniksu damarowego (firmy Renesans), 8-10 cz. obj. gorącej przegotowanej wody, $15 \mathrm{~cm}^{3}$ bieli tytanowej). Il. 13 - wygląd impastu bezpośrednio po nałożeniu, 13A - po upływie 6 tygodni - zauważalne zniszczenia w postaci spękań (fot. A. Cwynar) 

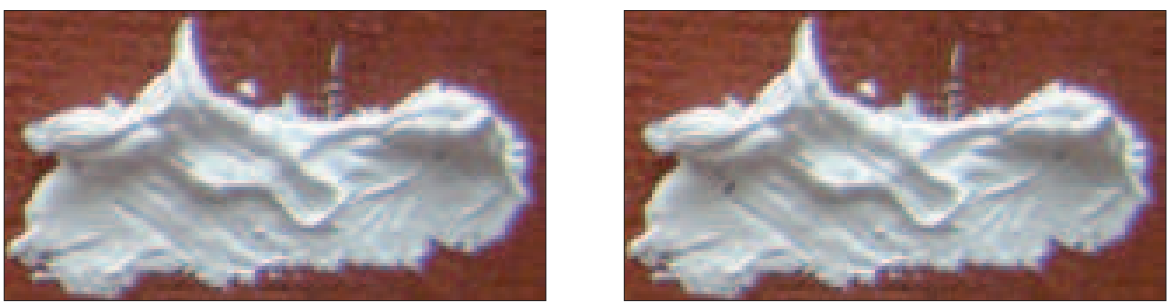

Il. 14, il. 14A. Przykład impastu z dodatkiem wypełniacza kredowego, na zaprawie „tłustej" o spoiwie woskowym - wodorozcieńczalnym (spoiwo nr 38: 1,5 cz. obj. gumy arabskiej (gotowy roztwór gumy arabskiej firmy Winsor\&Newton), 1 cz. obj. wosku pszczelego, 1 cz. obj. werniksu damarowego (firmy Renesans), 8-10 cz. obj. goracej przegotowanej wody, $15 \mathrm{~cm}^{3}$ bieli tytanowej). Il. 14 - wygląd impastu bezpośrednio po nałożeniu, $14 \mathrm{~A}$ - po upływie 6 tygodni - zauważalne niewielkie zniszczenia w postaci delikatnych spękań (fot. A. Cwynar)
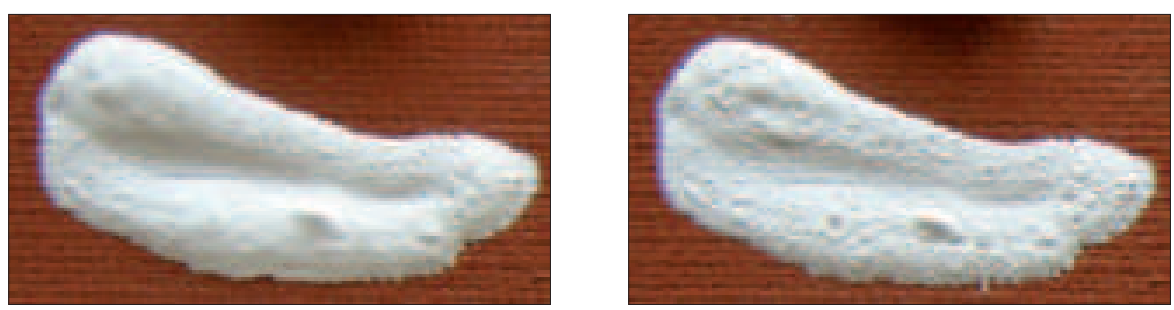

Il. 15, il. 15A. Przykład impastu, próby 2 - o rzadszej konsystencji, na zaprawie „półtłustej" o spoiwie akrylowym - wodorozcieńczalnym (spoiwo nr 42: dyspersja akrylowa (firmy Blik), $15 \mathrm{~cm}^{3}$ bieli tytanowej). Il. 15 - wygląd impastu bezpośrednio po nałożeniu, $15 \mathrm{~A}$ - po upływie 6 tygodni - zauważalne obniżenie wysokości impastu podczas wysychania (fot. A. Cwynar)
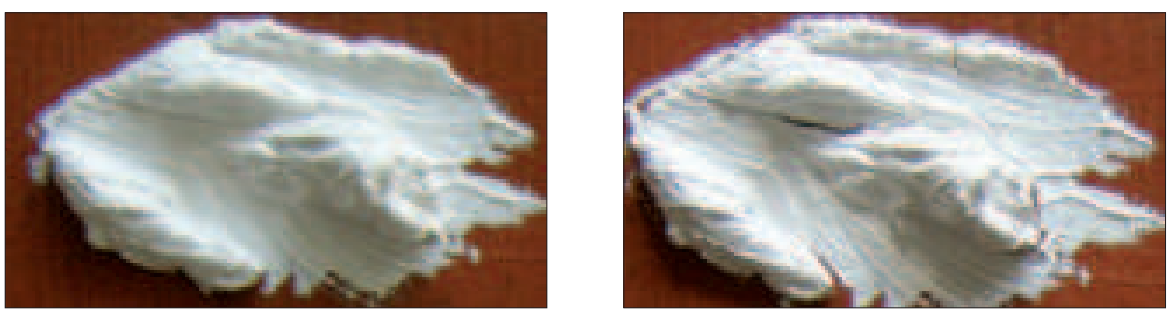

Il. 16, il. 16A. Przykład impastu, próby 1 - o gęstej konsystencji, na zaprawie „tłustej” o spoiwie akrylowym - wodorozcieńczalnym (spoiwo nr 42: dyspersja akrylowa (firmy Blik), $15 \mathrm{~cm}^{3}$ bieli tytanowej). Il. 16 - wygląd impastu bezpośrednio po nałożeniu, 16A - po upływie 6 tygodni - zauważalne spękania i odspojenia impastu (fot. A. Cwynar) 

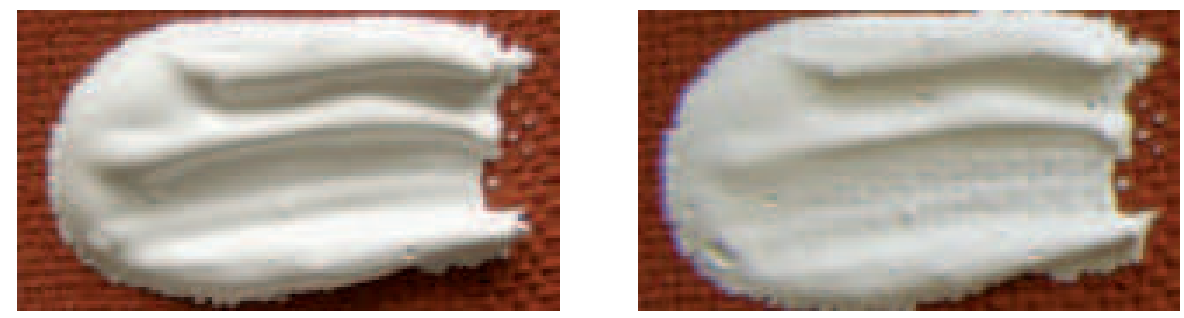

Il. 17, il. 17A. Przykład impastu na zaprawie „chudej” o spoiwie na bazie emulsji żółtkowej - typu „olej w wodzie” z dodatkiem gotowej past do impastu (spoiwo nr 48: Heavy gel medium (gotowa pasta do impastów firmy Amsterdam), farba temperowa (1 cz. obj. żółtka, 1cz. obj. oleju lnianego sykatywowanego, $15 \mathrm{~cm}^{3}$ bieli tytanowej). Il. 17 - wygląd impastu bezpośrednio po nałożeniu, 17A - po upływie 6 tygodni - zauważalne nieznaczne opadnięcie farby (fot. A. Cwynar)
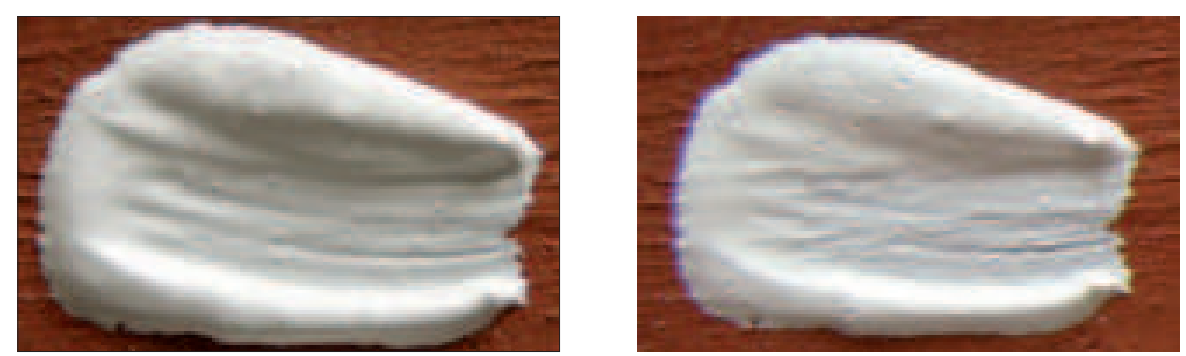

Il. 18, il. 18A. Przykład impastu na zaprawie „tłustej” o spoiwie na bazie emulsji żółtkowej - typu „olej w wodzie” z dodatkiem gotowej pasty do impastu (spoiwo nr 48: Heavy gel medium (gotowa pasta do impastów firmy Amsterdam), farba temperowa (1 cz. obj. żółtka, 1cz. obj. oleju lnianego sykatywowanego, $15 \mathrm{~cm}^{3}$ bieli tytanowej). Il. 18 - wygląd impastu bezpośrednio po nałożeniu, 18A - po upływie 6 tygodni - zauważalne nieznaczne opadnięcie farby (fot. A. Cwynar)
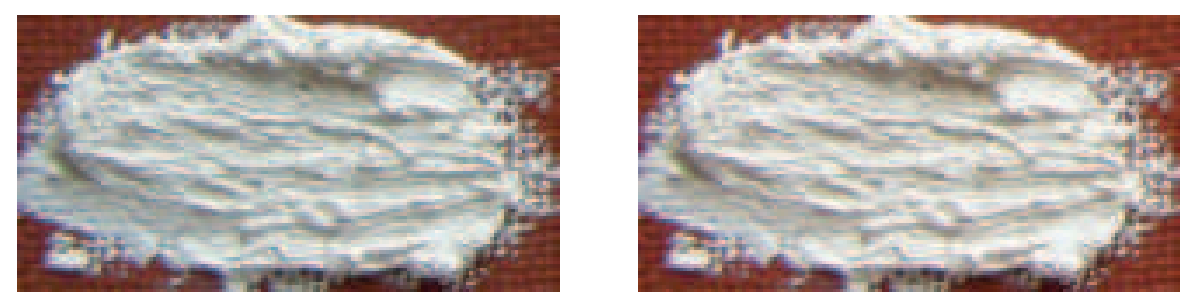

Il. 19, il. 19A. Przykład impastu, próby 1 - o gęstej konsystencji, na zaprawie „chudej” o spoiwie białkowym - nierozcieńczalnym w wodzie, na bazie emulsji żółtkowej - typu „woda w oleju” (spoiwo nr 15: 1 część jajka (całe jajko), 1 część mastyksu (25\% mastyks w olejku terpentynowym), $10 \mathrm{~cm}^{3}$ bieli tytanowej, 1 część farby olejnej (olej lniany firmy Renesans, $5 \mathrm{~cm}^{3}$ bieli tytanowej). Il. 19 - wygląd impastu bezpośrednio po nałożeniu, 19A - po upływie 6 tygodni - zauważalne nieznaczne spękania impastu. Impast ma powierzchnię chropowata, trudno się go nanosiło ze względu na zbyt gęstą konsystencję (fot. A. Cwynar) 

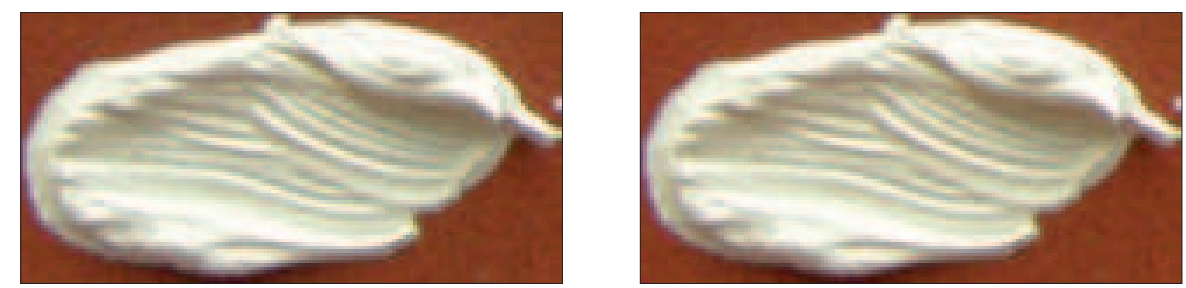

Il. 20, il. 20A. Przykład impastu, próby 2 - o rzadszej konsystencji, na zaprawie „tłustej” o spoiwie białkowym - nierozcieńczalnym w wodzie, na bazie emulsji żółtkowej - typu „woda w oleju” (spoiwo nr 15: 1 część jajka (całe jajko), 1 część mastyksu (25\% mastyks w olejku terpentynowym), $10 \mathrm{~cm}^{3}$ bieli tytanowej, 1 część farby olejnej (olej lniany firmy Renesans, $5 \mathrm{~cm}^{3}$ bieli tytanowej). Il. 20 - wygląd impastu bezpośrednio po nałożeniu, 20A - po upływie 6 tygodni - impast ma plastycznie ukształtowaną powierzchnię z odwzorowanym duktem pędzla (fot. A. Cwynar)
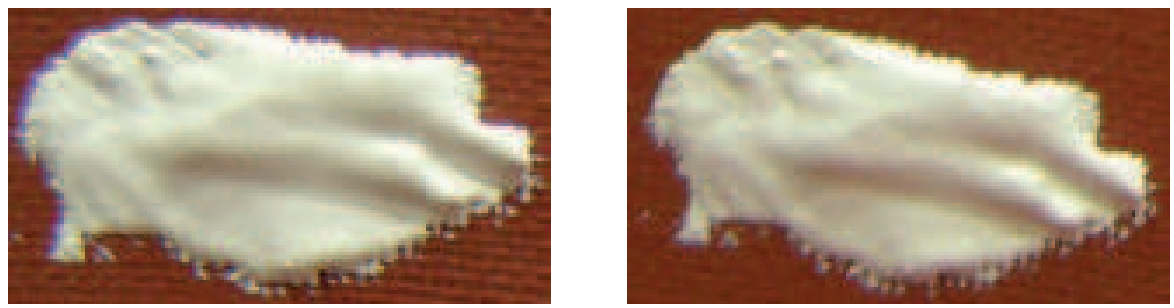

Il. 21, il. 21A. Przykład impastu, próby 1 - o gęstej konsystencji, na zaprawie „chudej” o spoiwie białkowym - nierozcieńczalnym w wodzie, na bazie emulsji kazeinowej - typu "woda w oleju" (spoiwo nr 22: 1 cz. obj. tempery kazeinowej (3 cz. obj. roztworu kazeiny, $1 \mathrm{cz}$ obj. oleju lnianego gotowanego, $5 \mathrm{~cm}^{3}$ bieli tytanowej), $1 \mathrm{cz}$. bieli olejnej (olej lniany sykatywowany, $5 \mathrm{~cm}^{3}$ bieli tytanowej). Il. 21 - wygląd impastu bezpośrednio po nałożeniu, $21 \mathrm{~A}$ - po upływie 6 tygodni - nie zaobserwowano spękań i odspojeń (fot. A. Cwynar)
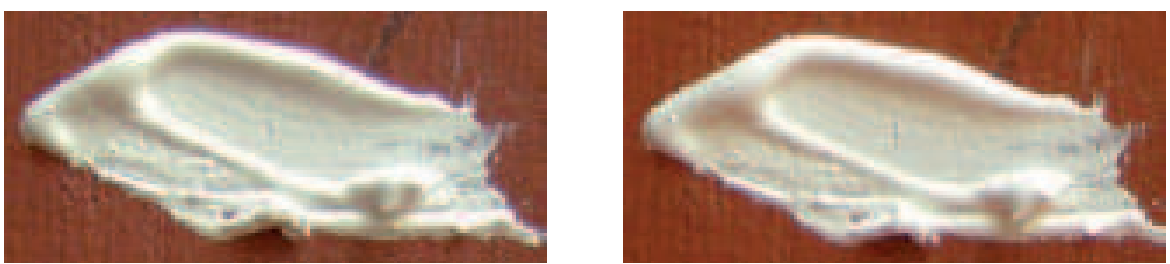

Il. 22, il. 22A. Przykład impastu, uzyskanego szpachla, na zaprawie „tlustej” o spoiwie białkowym - nierozcieńczalnym w wodzie, na bazie emulsji kazeinowej - typu „woda w oleju” (spoiwo nr 22: 1 cz. obj. tempery kazeinowej (3 cz. obj. roztworu kazeiny, 1 cz. obj. oleju lnianego gotowanego, $5 \mathrm{~cm}^{3}$ bieli tytanowej), $1 \mathrm{cz}$. bieli olejnej (olej lniany sykatywowany, $5 \mathrm{~cm}^{3}$ bieli tytanowej). Il. 22 - wygląd impastu bezpośrednio po nałożeniu, 22A - po upływie 6 tygodni - nie zaobserwowano spękań i odspojeń (fot. A. Cwynar) 

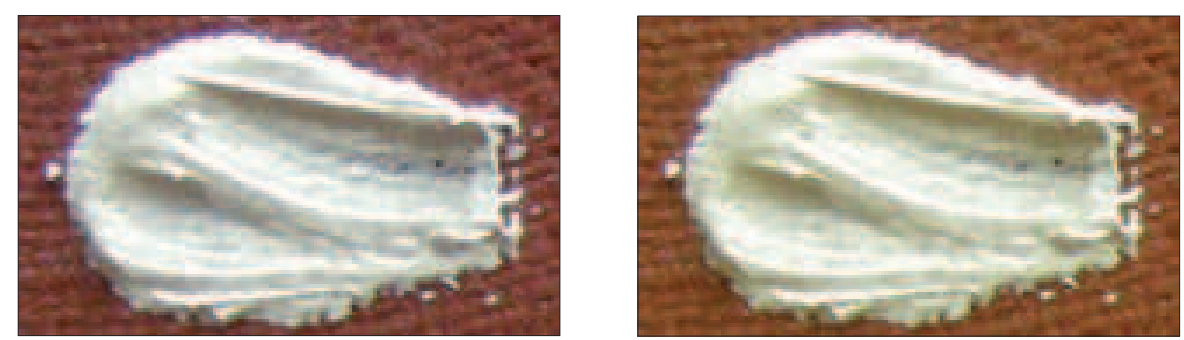

Il. 23, il. 23A. Przykład impastu, próby 1 - o gęstej konsystencji, na zaprawie „chudej” o spoiwie olejno-żywicznym - nierozcieńczalnym w wodzie (spoiwo nr 26: $1 \mathrm{cz}$. obj. oleju lnianego sykatywowanego, $1 \mathrm{cz}$. obj. mastyks w olejku terpentynowym 1:2, $15 \mathrm{~cm}^{3}$ bieli tytanowej). Il. 23 - wygląd impastu po nałożeniu, 23A - po upływie 6 tygodni - nie zaobserwowano spękań i odspojeń (fot. A. Cwynar)
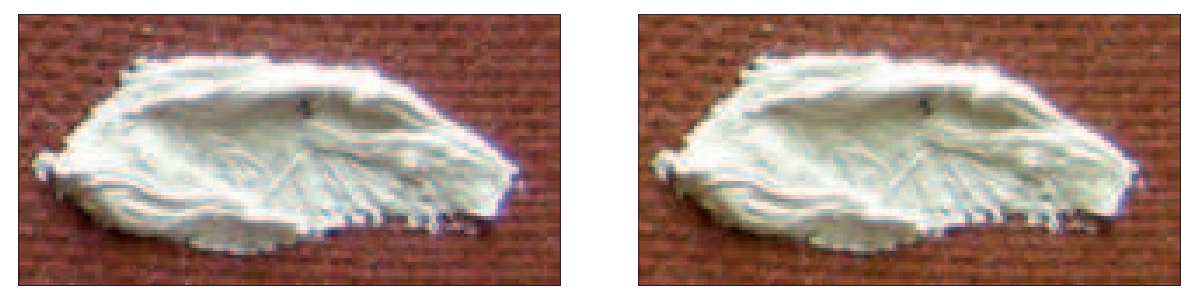

Il. 24, il. 24A. Przykład impastu, próby 5 - z wypełniaczem kredowym, na zaprawie „,chudej” o spoiwie olejno-żywicznym - nierozcieńczalnym w wodzie (spoiwo nr 26: 1 cz. obj. oleju lnianego sykatywowanego, $1 \mathrm{cz}$. obj. mastyks w olejku terpentynowym 1:2, $15 \mathrm{~cm}^{3}$ bieli tytanowej). Il. 24 - wygląd impastu bezpośrednio po nałożeniu, 24A - po upływie 6 tygodni - nie zaobserwowano spękań i odspojeń (fot. A. Cwynar)
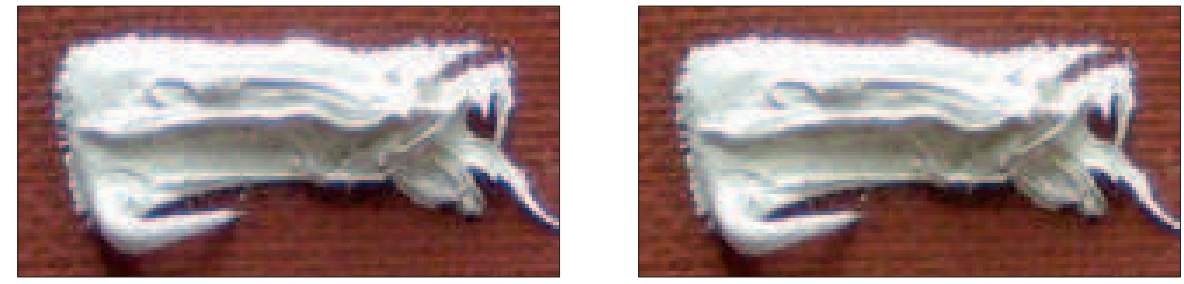

Il. 25, il. 25A. Przykład impastu, próby 1 - o gęstej konsystencji, na zaprawie „chudej” o spoiwie na bazie emulsji woskowej - nierozcieńczalnej w wodzie, typu „w/o” (spoiwo nr 39: 1 cz. obj. wosku pszczelego, 1 cz. obj. terpentyny weneckiej, biel tytanowa olejna (olej lniany firmy Renesans, $15 \mathrm{~cm}^{3}$ bieli tytanowej)). Il. 25 - wygląd impastu bezpośrednio po nałożeniu, $25 \mathrm{~A}$ - po upływie 6 tygodni - nie zaobserwowano spękań i odspojeń (fot. A. Cwynar) 

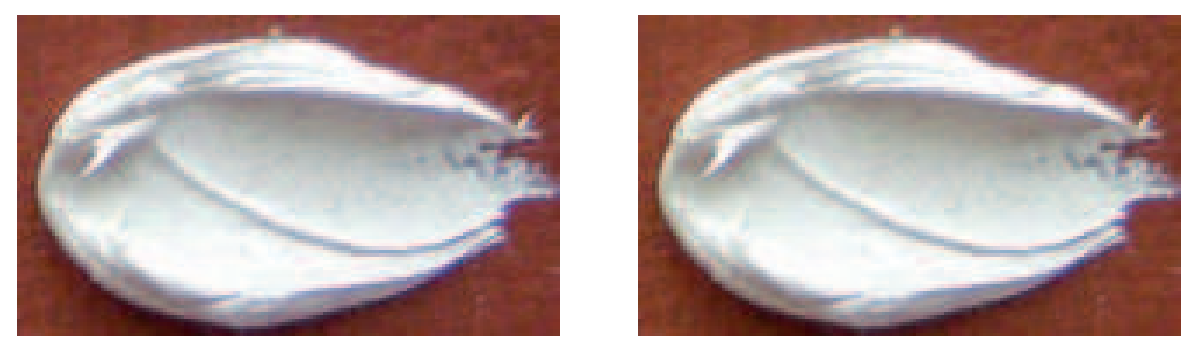

Il. 26, il. 26A. Przykład impastu uzyskanego za pomoca szpachli na zaprawie „tłustej” o spoiwie na bazie emulsji woskowej - nierozcieńczalnej w wodzie, typu „w/o” (spoiwo nr 39: 1 cz. obj. wosku pszczelego, 1 cz. obj. terpentyny weneckiej, biel tytanowa olejna (olej lniany firmy Renesans, $15 \mathrm{~cm}^{3}$ bieli tytanowej)). Il. 26 - wygląd impastu bezpośrednio po nałożeniu, 26A - po upływie 6 tygodni - nie zaobserwowano spękań i odspojeń (fot. A. Cwynar)
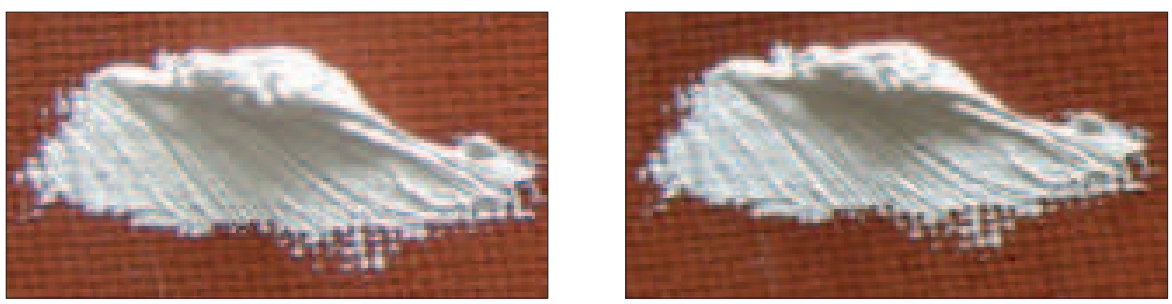

Il. 27, il. 27A. Przykład impastu, próby 1, na zaprawie „chudej” o spoiwie nierozcieńczalnym w wodzie, na bazie żywicy epoksydowej (spoiwo nr 45: 1 cz. obj. żywicy epoksydowej (po połączeniu z utwardzaczem w stosunku 3:1, firmy Bresciani), 1 cz. oleju lnianego (firmy Renesans), $15 \mathrm{~cm}^{3}$ bieli tytanowej). Il. 27 - wygląd impastu bezpośrednio po nałożeniu, 27A - po upływie 6 tygodni - nie zaobserwowano spękań i odspojeń (fot. A. Cwynar)
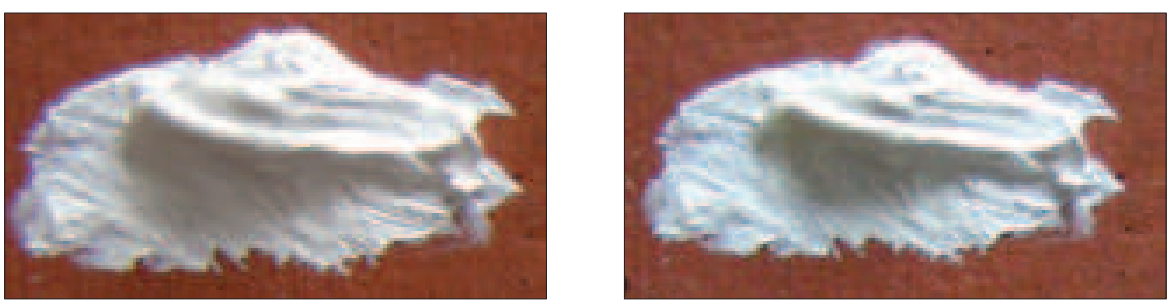

Il. 28, il. 28A. Przykład impastu, próby 2, na zaprawie „tłustej” o spoiwie nierozcieńczalnym w wodzie, na bazie żywicy epoksydowej (spoiwo nr 45: 1 cz. obj. żywicy epoksydowej (po połączeniu z utwardzaczem w stosunku 3:1, firmy Bresciani), 1 cz. oleju lnianego (firmy Renesans), $15 \mathrm{~cm}^{3}$ bieli tytanowej). Il. 28 - wygląd impastu bezpośrednio po nałożeniu, 28A - po upływie 6 tygodni - nie zaobserwowano spękań i odspojeń (fot. A. Cwynar) 